\title{
Success and failure of grassroots innovations for addressing climate change: the case of the Transition Movement
}

Article

Accepted Version

Feola, G. and Nunes, R. (2014) Success and failure of grassroots innovations for addressing climate change: the case of the Transition Movement. Global Environmental Change, 24. pp. 232-250. ISSN 0959-3780 doi: https://doi.org/10.1016/j.gloenvcha.2013.11.011 Available at https://centaur.reading.ac.uk/36095/

It is advisable to refer to the publisher's version if you intend to cite from the work. See Guidance on citing.

To link to this article DOI: http://dx.doi.org/10.1016/j.gloenvcha.2013.11.011

Publisher: Elsevier

All outputs in CentAUR are protected by Intellectual Property Rights law, including copyright law. Copyright and IPR is retained by the creators or other copyright holders. Terms and conditions for use of this material are defined in the End User Agreement. 


\section{CentAUR}

Central Archive at the University of Reading

Reading's research outputs online 


\title{
Success and failure of grassroots innovations for addressing climate change: the case of the Transition Movement.
}

Giuseppe Feola, Department of Geography and Environmental Science, University of Reading

Richard Nunes, School of Real Estate and Planning, University of Reading

Corresponding author:

Giuseppe Feola

Department of Geography and Environmental Science,

University of Reading, Whiteknights

RG66AB Reading, United Kingdom

Tel. 0044118378 7496, Fax. 0044118975 5865, Email: g.feola@reading.ac.uk

\begin{abstract}
Grassroots innovations emerge as networks generating innovative solutions for climate change adaptation and mitigation. However, it is unclear if grassroots innovations can be successful in responding to climate change. Little evidence exists on replication, international comparisons are rare, and research tends to overlook discontinued responses in favour of successful ones. We take the Transition Movement as a case study of a rapidly spreading transnational grassroots network, and include both active and non-active local transition initiatives. We investigate the replication of grassroots innovations in different contexts with the aim to uncover general patterns of success and failure, and identify questions for future research. An online survey was carried out in 23 countries $(\mathrm{N}=276)$. The data analysis entailed testing the effect of internal and contextual factors of success as drawn from the existing literature, and the identification of clusters of transition initiatives with similar internal and contextual factor configurations. Most transition initiatives consider themselves successful. Success is defined along the lines of social connectivity and empowerment, and external environmental impact. We find that less successful transition initiatives might underestimate the importance of contextual factors and material resources in influencing success. We also find that their diffusion is linked to the combination of local-global learning processes, and that there is an incubation period during which a transition initiative is consolidated. Transition initiatives seem capable of generalising organisational principles derived from unique local experiences that seem to be effective in other local contexts. However, the geographical locations matter with regard to where transition initiatives take root and the extent of their success, and 'place attachment' may have a role in the diffusion of successful initatives. We suggest that longitudinal comparative studies can advance our understanding in this regard, as well as inform the changing nature of the definition of success at different stages of grassroots innovation development, and the dynamic nature of local and global linkages.
\end{abstract}

\section{Citation:}

Feola, G., Nunes, J.R. (2014) Success and failure of Grassroots Innovations for addressing climate change: the case of the Transition Movement. Global Environmental Change 24, 232-250. 


\section{Introduction}

With a growing body of evidence on human activity induced changes to the Earth's climate (IPCC, 2007) and international governance regimes faltering (Young, 2011), growing attention has been given to local climate change adaptation and mitigation responses. A significant part of this research has focused on urban policy-making and governance (e.g. Burch, 2010; Moloney et al., 2010; Castán Broto and Bulkeley, 2013), including a complementary emphasis on business- or market-led innovation (Grin et al., 2010). Such research has often focused on top-down programmes and on the individual and contextual factors that local authorities can act upon to facilitate behavioural change towards less carbon intensive practices (Bulkeley, 2005; Bulkeley and Kern, 2006; Moloney et al., 2010). However, growing attention has been paid to yet another type of phenomenon, namely 'grassroots innovations', which are not led by municipal institutions, but rather emerge as 'networks of activists and organisations generating novel bottom-up solutions for sustainable development' (Seyfang and Smith, 2007, p. 585; see also Leach et al., 2012).

In this paper we examine the success and failure of grassroots innovations in addressing climate change. To do this, we take the Transition Movement as a case study (Transition Network, 2012). The Transition Movement is a network of local initiatives, which is often presented as a case of success due to its rapid worldwide diffusion and increasing public visibility, although recent analyses of individual cases have uncovered some barriers to its development and examples of failure (Hopkins, 2011; Smith, 2011; Wells, 2011; Seyfang and Haxeltine, 2012). As a result of its formalised international organisational structure and its wide geographical distribution, the Transition Movement represents a relevant case study in that it allows for an exploration of the factors of success and failure of grassroots innovations in different local contexts. We aim to improve the understanding of grassroots innovations and, in particular, to investigate the conditions for their success as a form of response to climate change. What is a successful transition initiative, and what factors facilitate or contribute to its success?

The paper is structured as follows. After a brief overview of the literature on grassroots innovations, we identify the knowledge gaps on the research problem of success and failure of grassroots innovations and state the research questions that guided this study. We then move to the presentation of the methodology, which included a survey-based data collection followed by statistical analysis and clustering of transition initiatives. A presentation of the results follows, whereby we test the initial hypotheses and uncover some configurations of internal and external conditions for success. Finally we discuss this study's results, considering the literature on grassroots innovations and suggesting some promising avenues for future research.

\section{Theoretical context}

\subsection{Principles of transition}

The notion of 'transition' has become increasingly central to futures-oriented thinking (Moloney et al., 2010; Mulugetta et al., 2010; Brown et al., 2012), although the term 'transition' is often interpreted differently in practice than in academia, e.g. in transition theory and transition management studies (Haxeltine and Seyfang, 2009). Brown et al. suggest three principles of transition: philosophies, policies and practices. They claim the term is 'increasingly being used to combine different forms of transition - lifecourse, environmental, and political-economic' (Brown et al., 2012, p. 1608). The combination of different forms of transition assumes aggregation, consolidation and standardisation of learning processes that underpin the successful growth and development of grassroots innovations. Nevertheless, recent studies illustrate that some fields of grassroots innovations may replicate and develop unencumbered by weak learning processes as a result of peer-to-peer knowledge dissemination (Seyfang and Haxeltine, 2012; Seyfang and Longhurst, 2013). The different political connotations of the term 'transition', and the consequent discord over imagined futures, challenge the assumptions that iterative learning processes and experimentation may lead to a convergence of pro-environmental behaviour towards climate change - 
from alternative economies to retrofitting the built environment (TRAPESE, 2008; Holloway and Sergi, 2010).

Secondly, driven forward by such imminent threats as climate change and peak oil, Brown et al. (2012) also suggest transition approaches rely on compulsion or affective governance, i.e. 'a sense that the (risk-laden) future is pressing upon the present perhaps more than ever before' (Brown et al., 2012 , p. 1619), to hold together community initiatives (see also Smith, 2011). The compulsion may involve the interdependence between local initiatives and non-local networks, whereby the former enact transition practices and experiments informed by the repetitive iteration of narratives of the riskladen future (Späth and Rohracher, 2012). Though, whilst such partnerships may encourage grassroots innovation success by legitimising, institutionalising and therewith embedding alternative practices into standardised processes, a trade-off between successful diffusion (i.e. replication of experimentation) and innovation control (in the face of diverse values and expectations in different niches) may exist (Ornetzelder and Rohracher, 2013).

Lastly, whilst relying on the rhetoric of global imminent trends, grassroots innovations are the product of local experimentation (North, 2010). Albeit deployed in different ways, Brown et al. (2012) suggest that the spaces, places and scales of transition approaches or their emplacement enable futures narratives to hold together. Transition, they claim, 'does not work without (local) places because those places offer the milieu - and the affective attachments - through which generic senses of responsibility, resilience, and relatedness may be most easily imagined and held together' (p. 1620). Feitelson (1991, cf. Devine-Wright, 2013) first proposed that research on human responses to global climate change had neglected attachment to place (Scannell and Gifford, 2010 for review of definitions), and that these actions could be felt both locally where people live and globally. DevineWright (2013) reintroduced this debate to Global Environmental Change, exploring whether cognitive proximity to climate change, as a global problem, can emerge from both global as well as local concerns. The success of grassroots innovations may be rooted in pre-existing networks, and interscalar arrangements, which has drawn recent attention to the spatial contexts, or space, scale and place, of socio-technical transitions (Hodson and Marvin, 2010; Coenen et al., 2012; Truffer and Coenen, 2012). In other words, the pro-environmental behaviour associated with grassroots innovations may be neither only 'local' nor 'global', and the local and global linkages to the places, and events through which the practice of adaptation and mitigation is performed, contested and validated, is a pertinent consideration of the diffusion and scale-up of community-led initiatives (Späth and Rohracher, 2012; Nunes, 2013).

\subsection{Innovation from the bottom up}

Grassroots innovations support the processes of local niche creation, i.e. the incubation of sociotechnical innovation in the face of mainstream values, technologies and actors (Seyfang and Longhurst, 2013), although the question remains whether, given the strong local specificity of cultural, social and technological landscapes that inform local grassroots innovations, any generalisation can be drawn on the experiences of community responses to global environmental change (Devine-Wright and Wiersma, 2013). Grassroots innovations may be connected to 'global action networks' (Glasbergen, 2010) and interdependent with the 'global' (Wilson, 2012), whilst retaining a strong connotation to social innovation and resilience through alternatives to conventional markets or a promotion of the 'local' (Glasbergen, 2010; Mayer and Knox, 2010; Devine-Wright and Wiersma, 2013). Because grassroots innovations involve less powerful non-business actors, they are not always visible to and supported by policy makers, and therefore their potential remains largely underdeveloped (Bergman et al., 2010). Nevertheless, many positive accounts of specific grassroots innovations have been provided and grassroots innovations are often seen as niches of experimentation of new social, cultural, economic, technological arrangements (Seyfang and Haxeltine, 2012; Ornetzelder and Rohracher, 2013). It is recognised that grassroots innovations can act as incubators of the social change that is needed to respond to, and minimise, future environmental 
change (O'Brien, 2012). Grassroots innovations often challenge the status quo (i.e. technologies, values, practices) and promote new forms of organisation of social and economic life (e.g. local currencies), and alternative systems of provision (such as local food systems and community energy) (Seyfang 2011; Peters et al., 2012).

There is a substantive distinction between technological innovation, and social innovation (Howaldt and Schwarz, 2010). Whereas the former is centred on technological artefact the latter is understood through social everyday practice. Moulaert et al. (2005) identify three dimensions of this practice. The first of these dimensions is addressing human needs, followed by adjusting the dynamics of social relations with the aim of increasing levels of participation and inclusivity, and lastly increasing the capability and access to resources. Thus, we extend the focus of innovation on tangible improvements or solutions to an appreciation of the 'change of attitudes, behaviour, [and] perceptions' (Neumeier, 2012 , p. 55), as well as to the potential for new hybrid or emergent forms of collaborative action that may be successful only in generating immaterial or intangible benefits (Howaldt and Schwarz, 2010). Finally, we recognise that what is novel or 'new' is not necessarily socially desirable, especially considering the potential trade-off between successful diffusion of grassroots innovations and innovation control (Ornetzelder and Rohracher, 2013).

\subsection{Factors of grassroots innovation success and failure: knowledge gaps}

While the role of 'community' is central to grassroots innovations (Aiken, 2012), it has been shown that grassroots innovations do not always internally operate as smoothly as idealised, or function as inclusive and supportive communities of practice (Mulugetta et al., 2010; Walker, 2011). With reference to the links between these communities and the wider community of a place, the literature has highlighted several factors that hinder the diffusion of grassroots innovations. For example, it has been noted that grassroots innovations, like many volunteer organisations, often struggle with securing and sustaining participation over time (Seyfang and Smith, 2007; Hoffman and High-Pippert, 2010; Middlemiss and Parrish, 2010; Smith, 2011; Wells, 2011). Grassroots innovations often rely on volunteers, which limit their ability to promote innovation in the community (Kirwan et al., 2013; Ornetzelder and Rohracher, 2013), and often rely on low levels of financial resources (Middlemiss and Parrish, 2010), which have been shown to be key to supporting learning processes (Seyfang and Longhurst, 2013). Ideological disputes, e.g. between political and apolitical strands, also have been identified to create internal conflict and to act as a barrier to the successful development of grassroots innovations (Smith, 2011), while the management of expectations has been argued to be one of the most difficult aspects for the internal group governance of grassroots innovations (Seyfang and Longhurst, 2013). Finally, grassroots innovations do not always mirror the diversity (e.g. ethnic) of local communities, consequently struggling to establish strong links with the wider community of place (Seyfang and Smith, 2007; Smith, 2011; Wells, 2011). On the other hand, networking with other local or global actors, including other grassroots innovations, can significantly support the process of niche building (Seyfang and Longhurst, 2013).

Therefore, the literature casts doubt on grassroots innovations' ability to effectively trigger sociotechnical change in response to environmental change. Such evidence suggests that there is a need for better understanding of 'the internal dynamics and external factors that limit and enable success' (Mulugetta et al., 2011, p. 7544) and the 'pre-conditions, contexts and dynamics' of grassroots innovations (Ornetzelder and Rohracher, 2013, p. 11; see also Seyfang and Smith, 2007; Scott-Cato and Hillier, 2010; Walker, 2011). It has been argued that the 'research base evaluating communitybased carbon initiatives is limited in scope and depth' (Walker, 2011, p. 779), and that little evidence or lessons learned exists on scaling-up and replication (Bergman et al., 2010, Walker, 2011). In addition, it has been suggested that 'future research should focus on missed opportunities, and discontinued initiatives to discuss the role of local settings and structural conditions from a contrasting point of view' (Ornetzelder and Rohracher, 2013, p. 11). Little research also has been carried out to systematically quantify the impacts of grassroots innovations (e.g. Church and Elster, 2002; Barthelmie et al., 2008), whereby evidence of this impact tends to be anecdotal (Hopkins, 2011; Merritt and Stubbs, 2012). In fact, research on grassroots innovations tends to be based on data-rich, 
in-depth case studies, and international comparisons are rare (Bergman et al., 2010; Castán Broto and Bulkeley, 2013). To the best of the authors' knowledge, no study so far has attempted to uncover patterns of success and failure of grassroots innovations across countries. Mapping out these patterns quantitatively would complement in-depth qualitative analysis (Seyfang and Smith, 2007), and provide indications and lessons learned of potential use to those actors (communities, policy-makers and researchers) who are involved in the governance of grassroots innovations and social innovation in the face of environmental change.

\section{Methodology}

This study addressed the diffusion (i.e. replication) of grassroots innovations in different contexts, and included both active and non-active (i.e. discontinued) initiatives in the Transition Movement, to allow for a comparison between the two. We investigated the factors that facilitate or hinder the success of transition initiatives worldwide, with the aim to i) uncover general patterns of success and failure of grassroots innovations in different contexts and ii) identify research questions with high potential and interest for future research. The study was guided by two overarching research questions: i) what is a successful transition initiative? and ii) what factors facilitate or contribute to the success of a transition initiative?

\subsection{Case study: Transition Movement}

This study takes the network of local transition initatives, i.e. the Transition Movement, as a case study (Transition Network, 2012). The Transition Movement originated in Totnes, Devon (United Kingdom) in 2006 (Hopkins, 2011). It seeks to deal with climate change, shrinking supplies of cheap fossil fuels ('peak oil'), and a growing recognition of the downsides of the current economic model, made apparent by the 2008 financial crisis (Smith, 2011). The Transition Movement promotes 'energy descent' and local resilience to be achieved through the 'unleashing' of the creativity, motivation and knowledge of communities. A major theme in the Transition Movement is that of relocalisation, which entails the reduction of the dependency on unstable global markets and increasingly more expensive transport. Re-localisation also concerns the willingness of 'transitioners' to take direct action, which is usually focused on a rather definite set of themes, among which food, transport, energy and local currencies are the most frequent (Hopkins, 2011). The Transition Movement has developed in time a set of guidelines, originally modelled on the first transition initiative in Totnes. A Transition Handbook (Hopkins, 2008), a Transition Initiatives Primer (Brangwyn and Hopkins, 2008) and Transition Companion (Hopkins, 2011) have been published. Permaculture is among the most significant intellectual influences of the movement, i.e. a holistic and problem-solving design approach originally developed by Holmgren (2004). The transition model (Brangwyn and Hopkins, 2008) is a set of 12 'steps to transition' that are meant to guide communities to set up a successful transition initiative (Table A.6 in Electronic Supplementary Materials). Communities can adapt these steps to their specific case, and therefore they do not need to make up a compulsory list. They were recently re-elaborated as the 'ingredients' of transition (Hopkins, 2011). The Transition Movement is a transnational grassroots movement active in 41 countries and organized by the Transition Network, which is structured in regional and national hubs, with a central point of reference in the transition initiative in Totnes (United Kingdom). The Transition Network develops the movement's overall strategy and transition guidelines, and delivers training for transitioners, consultancy services, facilitation of information exchange and learning among local transition initiatives. More importantly, the Transition Network also established a system of branding, according to which communities that desire to be recognised as 'official' members of the network need to comply with a set of criteria such as having attended a training session, having drafted and approved a constitution, be composed of at least four or five people and demonstrate commitment to network with others, including locally and with authorities (Brangwyn and Hopkins, 2008; Smith, 2011). Transition initiatives that are inspired by the Transition Movement principles, but that do not comply with these criteria, are listed as 'muller' initiatives.

\subsection{Success and failure of transition initiatives}


Given the diversity of transition initiatives and their activities in different contexts (Hopkins, 2011; Wells, 2011), it can be controversial to identify universal indicators of success of a transition initiative. Ornetzelder and Rohracher (2013), for example, argued that initiatives may tend to define success either in terms of their internal interactions, or of the external impact, and Devine-Wright and Wiersma (2013) suggested that the former might prevail over the latter. On the other hand, because transition initiatives by and large follow shared guidelines as presented for example in the Transition Primer (Brangwyn and Hopkins, 2008) or the Transition Companion (Hopkins, 2011), some basic characteristics can be pointed out, or discounted for the differences due to specific local configurations. Following a traditional distinction in social indicator research (e.g. Veenhoven, 2002), we measured the degree of success of a transition initiative through two measures, a subjective and an objective one. The former focused on 'soft' aspects and related to the respondent's awareness and positional evaluation of the transition initiative, while the latter considered 'hard' facts that did not depend on the respondent's awareness or his/her evaluation (Veenhoven, 2002). The subjective measure of success consisted of a Likert scale ('Overall, do you consider your transition initiative very successful, fairly successful, not very successful, or not successful at all?') coupled with an open question to document the subjective idea of success ('What do you think are the three most important characteristics of a successful transition initiative?'). The objective measure of success considered the number of members or people involved in the transition initiative (i.e. critical mass) as suggested by Mulugetta et al., 2010, the duration of the transition initiative, and the progress made towards the 12 steps to transition (proxy for the level of activity and development). The latter was preferred to the 'ingredients' of transition as a measure of activity and development, because the 'ingredients' were only recently introduced and were therefore not widespread among transition initiatives.

\subsection{Explanatory factors}

Considering earlier evidence on specific case studies of transition initiatives and grassroots innovations more broadly, five groups of interdependent factors that potentially influence the success of transition initiatives were considered: transition initiative characteristics, members, resources, organization and context, and respective hypotheses formulated (Table 1).

Many of the selected factors do not identify uni-, but bi-directional relationships between the transition initiative as an incubator of innovative niches and the socio-technical regimes (e.g. food, energy system). As shown by a growing body of literature on grassroots innovations (e.g. Smith et al., 2005; Smith and Raven, 2012), the transition initiative (i.e. niche) can play an active role in interacting with the context (i.e. other niches, the socio-technical regime) and thus contribute to shaping the conditions for its own success or failure. Consequently, many factors, especially among context and resources (Table 1) are endogenous and must be interpreted as pre-conditions but also as results of a transition initiative's interactions. Such complexity was considered in the data analysis and is discussed later on in this paper. A complete list of the variables measured in relation with each factor and their definition is available in the Electronic Supplementary Materials. 
Feola, G., Nunes, J.R. 2014. Success and failure of Grassroots Innovations for addressing climate change: the case of the Transition Movement. Global Environmental Change 24, 232-250.

Table 1. Explanatory factors considered in this study.

\begin{tabular}{|c|c|c|c|}
\hline Group of factors & Factor & Hypothesis. The transition initiative is more successful if: & Reference \\
\hline \multirow{6}{*}{$\begin{array}{l}\text { Transition } \\
\text { Initiative } \\
\text { characteristics }\end{array}$} & Rurality & $\begin{array}{l}\text { it is located ina rural/town/village setting in which social networks are denser and } \\
\text { social capital higher. }\end{array}$ & Smith (2011) \\
\hline & Legal status & $\begin{array}{l}\text { it has a legal status that facilitates the interaction with other actors such as local } \\
\text { authorities. }\end{array}$ & $\begin{array}{l}\text { Mulgan (2006); Brangwyn and Hopkins } \\
\text { (2008) }\end{array}$ \\
\hline & Activities/themes addressed & it addresses "easy" themes first and more complex ones at a later stage. & - \\
\hline & Years needed for a TI to become official & $\begin{array}{l}\text { it takes some time to become officially recognised by the Transition Network, i.e. it } \\
\text { goes through a significant consolidation and potentially a learning process. }\end{array}$ & 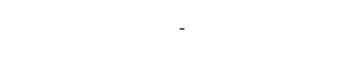 \\
\hline & Official vs mulling & $\begin{array}{l}\text { it is officially recognised by the Transition Network and therefore benefits of being } \\
\text { in such network in terms of e.g. knowledge exchange, training, partnership. }\end{array}$ & Brangwyn and Hopkins (2008) \\
\hline & Country & it is located in specific countries. & - \\
\hline \multirow[t]{5}{*}{ Members } & Age & most of its members are at a a specific age & $\begin{array}{l}\text { Middlemiss and Parrish (2010) } \\
\text { Hoffmann and High-Pippert (2010); }\end{array}$ \\
\hline & Skills & $\begin{array}{l}\text { a significant number of steering group members are specifically trained (e.g. group } \\
\text { management, motivation, coaching) }\end{array}$ & $\begin{array}{l}\text { Brangwyn and Hopkins (2008); Hopkins } \\
\text { (2011); Middlemiss and Parrish (2010); } \\
\text { Ornetzelder and Rohracher (2013) }\end{array}$ \\
\hline & Representation of minorities/diversity & it effectively represents the diversity of the local community & Smith (2011); Quilley (2012) \\
\hline & Large number of founders & the group of founders was big & Middlemiss and Parrish (2010) \\
\hline & Educational level & $\begin{array}{l}\text { a significant number of steering group members have high educational levels and } \\
\text { therefore skills that might be critical in the transition initiative development }\end{array}$ & Middlemiss and Parrish (2010) \\
\hline \multirow[t]{8}{*}{ Organisation } & Recruitment & it actively recruits its members & $\begin{array}{l}\text { Hoffmann and High-Pippert (2010); Wells } \\
\text { (2011) }\end{array}$ \\
\hline & Paid staff & it can rely on paid staff and therefore does not over-rely on volunteers & Wells (2011) \\
\hline & Internal conflict/Ideology & it can limit internal ideological conflict and/or managed it positively & Seyfang and Smith (2007); Smith (2011) \\
\hline & Steering group & it has a steering group & $\begin{array}{l}\text { Brangwyn and Hopkins (2008); Hopkins } \\
\text { (2011) }\end{array}$ \\
\hline & Size of steering group & it has a large steering group & Brangwyn and Hopkins (2008) \\
\hline & Internal communication & it manages internal communication well & $\begin{array}{l}\text { Brangwyn and Hopkins (2008); Hopkins } \\
\text { (2011); Ornetzelder and Rohracher (2013) }\end{array}$ \\
\hline & External communication & it manages external comunication well & $\begin{array}{l}\text { Brangwyn and Hopkins (2008); Hopkins } \\
\text { (2011) }\end{array}$ \\
\hline & Internal organization by subgroups & it is organised in subgroups (e.g. thematic or project-based) & Brangwyn and Hopkins (2008) \\
\hline \multirow[t]{3}{*}{ Resources } & Infrastructure & it utilises critical infrastructure (e.g. meeting rooms, computers) & $\begin{array}{l}\text { Hoffmann and High-Pippert (2010); } \\
\text { Middlemiss and Parrish (2010) }\end{array}$ \\
\hline & Funding & it can secure sources of funding & $\begin{array}{l}\text { Seyfang and Smith (2007); Middlemiss and } \\
\text { Parrish (2010) }\end{array}$ \\
\hline & Time resources & $\begin{array}{l}\text { its members dispose of significant time to dedicate to the transition initiative's } \\
\text { activities }\end{array}$ & Middlemiss and Parrish (2010) \\
\hline \multirow[t]{4}{*}{ Context } & Pre-existence of bottom-up initiatives & it builds on a pre-existing group (e.g. grassroots movement, NGO) & $\begin{array}{l}\text { Wells (2011); Ornetzelder and Rohracher } \\
\text { (2013) }\end{array}$ \\
\hline & Pre-existence of participatory democracy & $\begin{array}{l}\text { it is located in a context in which there are forms of participatory democracy which } \\
\text { facilitate public participation in local governance }\end{array}$ & Wells (2011) \\
\hline & $\begin{array}{l}\text { Cooperation/partnership with other } \\
\text { organizations }\end{array}$ & $\begin{array}{l}\text { it is able to cooperate or act in partnership with other organizations (e.g. local } \\
\text { authorities, business, media) }\end{array}$ & $\begin{array}{l}\text { Brangwyn and Hopkins (2008); Hopkins } \\
\text { (2011); Ornetzelder and Rohracher (2013) }\end{array}$ \\
\hline & Favourable context & $\begin{array}{l}\text { it is located in a context in which other actors(e.g. local authorities, business, } \\
\text { media) perceive the transition initiative positively }\end{array}$ & Mulgan (2006); Seyfang and Smith (2007) \\
\hline
\end{tabular}

\subsection{Data collection and analysis}

An online survey was carried out in May-August 2012 through the Surveymonkey platform (www.surveymonkey.com). A list of transition initiatives was built by mining information from the Transition Network website and the websites of its national hubs (United States of America, Ireland, Norway, Sweden, The Netherlands, Canada, Japan, Australia, United Kingdom, New Zealand, France, Portugal, Brazil, Germany, Switzerland, Spain, Chile and Italy). Each transition initiative was invited via email to fill in one questionnaire online. Where possible, the transition initiative's spokesperson was contacted, or otherwise a member of the transition initiative's steering group. In a few cases the invitation to participate in the survey was sent to a general email address provided as a contact point by the transition initiative. 1179 invitations were sent out and one reminder was sent out a month after the first invitation. In addition, the invitation was circulated through social networks where members of the Transition Movement are active (e.g. www.wiser.org, www.linkedin.com, transitionbrasil.ning.com), and websites (e.g. www.transitionresearchnetwork.org, www.reading.ac.uk/rep/transitionresearchreading). The national transition hubs of the Transition Network were also asked to circulate the invitation within their national network. In this way, we attempted to account for the fact that the population of transition initiatives is rather volatile, with new transition initiatives created and others potentially ceasing their activity very frequently, and not being under the radar of the listings that appear on, for example, the Transition Network websites and not necessarily being up to date. The questionnaire was available in English, French, German, Spanish, 
Portuguese and Italian. It had two separate but parallel question paths for active and non-active transition initiatives respectively. Data on the non-active transition initiatives related to their activity before being discontinued. The questions were structured into the following sections: transition initiative characteristics, members, success, organisation, resources and context.

The sample is self-selected and statistically non-representative of the population of transition initiatives. 276 valid questionnaires were returned. The transition initiative's spokesperson $(64 \%$ of cases) or another member of the transition initiative's steering group (29.6\% of cases), that is a person who can be assumed to have a good understanding and overview of the initiative, most frequently completed the questionnaires.The sample over-represents official versus mulling initiatives. With respect to country coverage, it slightly over-represents transition initiatives in the United Kingdom, Italy and Belgium whereas it slightly under-represents those in the United States of America and France (see Tables A.2 and A.3 in Electronic Supplementary Materials for more detail on the sample).

The data analysis was carried out with SPSS 19 in three stages. Firstly, a descriptive analysis of the dependent and independent variables was carried out (sections 4.1 and 4.2 below). Secondly, the driving hypotheses (Table 1) were tested in an exploratory bivariate analysis by means of Pearson Chi-Square test (for categorical variables) and Mann-Whitney U test (for numeric variables) (section 4.3 below). The effect sizes of the relationships were also estimated. Finally, we conducted a multivariate analysis by identifying clusters of transition initiatives via an SPSS two-step cluster analysis (Chiu et al., 2001) based on the variables that in the second stage we found to significantly correlate with the dependent variable (section 4.4 below). This procedure allows robust clusters to be identified in cases of presence of mixed numerical and categorical data, such as in this study. Although the assumption of variable independence did not hold in this study, this procedure has been shown to be robust against violation of this assumption (Norusis, 2012). Clustering allowed for the creation of transition initiative types and therefore was consistent with our research aim to identify general patterns of failure and success, while also accounting for their endogeneity and the high diversity of transition initiatives.

\section{Results}

\subsection{Success and failure of grassroots innovations}

The majority of transition initiatives was considered very or fairly successful. The percentage of successful transition initiatives was higher among active than non-active transition initiatives (Table 2).

Table 2. Level of success of transition initiatives.

\begin{tabular}{|c|c|c|c|c|c|c|}
\hline \multirow[t]{2}{*}{ Level of success } & \multicolumn{2}{|c|}{ Active transition initiatives } & \multicolumn{2}{|c|}{ Non-active transition initiatives } & \multicolumn{2}{|c|}{ All transition initiatives } \\
\hline & $\mathbf{N}$ & $\%$ & $\mathbf{N}$ & $\%$ & $\mathbf{N}$ & $\%$ \\
\hline Very successful & 36 & 13.9 & 0 & 0.0 & 36 & 13.0 \\
\hline Fairly successful & 170 & 65.6 & 3 & 17.6 & 173 & 62.7 \\
\hline Not very successful & 50 & 19.3 & 9 & 52.9 & 59 & 21.4 \\
\hline Not successful at all & 3 & 1.2 & 5 & 29.4 & 8 & 2.9 \\
\hline Total & 259 & 100.0 & 17 & 100.0 & 276 & 100.0 \\
\hline
\end{tabular}

Transition initiatives tended to define success in terms of four classes of factors, which we labelled human, external, organisation and resources. The responses to the open-ended survey question, as categorised according to these four factors, are shown in Table A.4 in the Electronic Supplementary Materials. The most highly mentioned characteristics (more than 80 times) of a successful transition initiative were the critical mass of active volunteers or members (human), which mirrors the community involvement in the grassroots initiative, and the ability to produce practical effects and achieve concrete goals in the community (organisation), i.e. not to limit the activities to informational or awareness-raising campaigns, but rather to produce change in, for example, technologies and practices. A highly cited (69 times) human factor was also the capacity to sustain motivation, enthusiasm and to promote a positive, ambitious approach. Among the human factors, another set of 
characteristics that was frequently mentioned (26 to 39 times) was related to the principles that guide participation in a successful transition initiative, which were considered to revolve around positivity, fun, conviviality and sense of community. Among the organisation factors, two areas can be distinguished: outreach and internal group management. For a transition initiative to be successful there is the need for developing outreach projects such as education and awareness-raising in the community. Moreover, vision and leadership were often considered essential characteristics of a successful transition initiative, together with the ability to manage internal activities in a simple, nonbureaucratic manner, democratically and creatively. Among the external factors, partnership with different local actors (with other informal organisations or the local authorities) was also frequently considered to contribute to the success of a transition initiative. Overall, it is apparent that the transition initiatives' subjective understanding of success tended to be based on internal rather than external factors.

Table 3 shows a summary of the descriptive statistics of the objective measure of success. A high variation is observed regarding number of members, steps undertaken, and the duration of the transition initiative. Membership of a transition initiative is a floating concept, since most transition initiatives did not require any official membership. Thus, the definition of what a member is varies markedly and might include volunteers but also people connected through mailing lists or social networks. A more meaningful indicator of success might therefore be the number of active transition initiative members, i.e. those who regularly participate in the transition initiative activities (e.g. general organisation, projects and events). In the majority of cases $(85 \%)$ and in particular in large transition initiatives, the number of active members was lower than the number of total members, while it coincided with the total number of members in the remaining $15 \%$ of sampled transition initiatives (not shown in table). Most of the transition initiatives addressed several of the " 12 steps to transition' suggested in the Transition Primer (Brangwyn and Hopkins, 2008). Regarding duration, on average the transition initiatives had existed for less than four years, which is consistent with the relatively recent development of the Transition Movement, especially outside the United Kingdom. In a marginal number of cases the transition initiative had existed for longer than the Transition Movement itself, which is possibly explained by the fact that the transition initiative pre-existed as a grassroots initiative in some other form, and formally adopted the transition model at a later stage.

As shown in Table 3, the transition initiatives that were very or fairly successful and those that were not very or not at all successful differed significantly regarding total members, active members, steps to transition undertaken and duration. In other words, the subjective measure of success initially considered in this study tends to correspond to the objective one.

Table 3. Total members, active members, steps addressed and duration by level of subjective success in active transition initiatives (Mann-Whitney $\mathrm{U}$ test).

\begin{tabular}{llcr}
\hline \multirow{2}{*}{ Variable } & \multicolumn{2}{c}{$\begin{array}{c}\text { Very or fairly } \\
\text { successful }\end{array}$} & $\begin{array}{c}\text { Not very or not } \\
\text { successful at all }\end{array}$ \\
\hline Total members (people) & Mean & $189.51^{* * *}$ & 42.87 \\
& Std dev & 275.37 & 66.71 \\
Active members (people) & Mean & $33.23^{* * *}$ & 10.42 \\
& Std dev & 35.24 & 7.33 \\
Steps of transition & Mean & $8.88^{* * *}$ & 6.79 \\
& Std dev & 2.21 & 2.44 \\
Duration (years) & Mean & $3.92^{* *}$ & 3.07 \\
& Std dev & $2.82^{*}$ & 1.21 \\
\hline
\end{tabular}

** Significant at 5\% level; *** Significant at $1 \%$ level 


\subsection{Factors of success and failure of grassroots innovations}

\subsubsection{Transition initiatives: characteristics and members}

Table 4 shows a summary of the variables associated with the transition initiative characteristics and members. The type of transition initiative was defined based on the conventional Transition Movement denomination (i.e. city/urban, village, town, forest, rural, island). The Transition Network recommends that transition initiatives include a formal organisation (Brangwyn and Hopkins, 2008), which may take several forms such as a trust, cooperative or charitable incorporated organisation, many of which are legal entities. The majority of transition initiatives $(64 \%)$ were constituted in a legal form and were officially recognised by the Transition Network (57\%). On average, it took transition initiatives 10 months to become official.

The most frequent primary overarching themes addressed by the transition initiatives were food (96 cases), energy (45 cases) and education (28) (multiple choice question). In 15 cases the transition initiatives first addressed more than one theme simultaneously (not shown in table).

Active and non-active transition initiatives differ markedly in relation to the proportion of city/urban initiatives (Table 4), the proportion of transition initiatives that received official recognition, and, among 'official' transition initiatives, the number of years that passed from foundation to official recognition.

Overall, less than half of the transition initiatives represent the diversity in their community fairly or very well. The transition initiative members predominantly belong to the age range 30-65 years old, which is reflected by the age range of the steering group members. In about half the cases the transition initiatives were founded on the basis of a pre-existing group (e.g. other grassroots organisation) and the group of founders was on average about 10 people, although a significant variation was observed in this respect.

The data illustrate a predominance of below-university degree level of education, but the response rate to the question regarding educational level was particularly low. In $29 \%$ of cases no steering group member of the transition initiative had ever attended a transition training course and in $18 \%$ of cases no member had attended permaculture training or had permaculture knowledge. Overall, on average about three steering group members had transition training from the Transition Network and two had permaculture training or knowledge, but high variation within groups was observed. The ratio of steering group members with transition or permaculture training to the total of steering group members was 0.45 and 0.36 (i.e. less than one in two and about one in three) respectively.

In summary, the most marked differences between active and non-active transition initiatives, regarding members, were observed in the representation of diversity in the community, the number of initial founders, and the number of steering group members with transition training. 
Feola, G., Nunes, J.R. 2014. Success and failure of Grassroots Innovations for addressing climate change: the case of the Transition Movement. Global Environmental Change 24, 232-250.

Table 4. Summary of characteristics and member variables (valid \% shown).

\begin{tabular}{|c|c|c|c|c|c|c|c|c|}
\hline \multirow[b]{2}{*}{ Factor } & \multirow[b]{2}{*}{ Variable } & & \multicolumn{2}{|c|}{$\begin{array}{c}\text { Active } \\
\text { transition } \\
\text { initiatives }\end{array}$} & \multicolumn{2}{|c|}{$\begin{array}{c}\text { Non-active } \\
\text { transition } \\
\text { initiatives }\end{array}$} & \multicolumn{2}{|c|}{$\begin{array}{c}\text { All transitior } \\
\text { initiatives }\end{array}$} \\
\hline & & & $\mathbf{N}$ & $\%$ & $\mathbf{N}$ & $\%$ & $\mathbf{N}$ & $\%$ \\
\hline \multirow{23}{*}{$\begin{array}{l}\text { Transition initiative } \\
\text { charactersitics }\end{array}$} & Type of transition initiative & City/urban & 85 & 32.8 & 9 & 52.9 & 94 & 247.4 \\
\hline & & Village & 24 & 9.3 & 1 & 5.9 & 25 & 65.8 \\
\hline & & Town & 104 & 40.2 & 5 & 29.4 & 109 & 286.8 \\
\hline & & Forest & 1 & 0.4 & 0 & 0.0 & 1 & 2.6 \\
\hline & & Rural & 37 & 14.3 & 1 & 5.9 & 38 & 100.0 \\
\hline & & Island & 8 & 3.1 & 1 & 5.9 & 9 & 23.7 \\
\hline & & Total & 259 & 100.0 & 17 & 100.0 & 276 & 100.0 \\
\hline & Legal form & Yes & 160 & 64.3 & 12 & 75.0 & 172 & 64.9 \\
\hline & & No & 89 & 35.7 & 4 & 25.0 & 93 & 35.1 \\
\hline & & Total & 249 & 100.0 & 16 & 100.0 & 265 & 100.0 \\
\hline & National hub & Yes & 6 & 2.3 & 0 & 0.0 & 6 & 2.2 \\
\hline & & No & 246 & 95.0 & 17 & 100.0 & 263 & 95.3 \\
\hline & & Do not know & 7 & 2.7 & 0 & 0.0 & 7 & 2.5 \\
\hline & & Total & 259 & 100.0 & 17 & 100.0 & 276 & 100.0 \\
\hline & Regional hub & Yes & 44 & 17.0 & 4 & 23.5 & 48 & 17.4 \\
\hline & & No & 201 & 77.6 & 12 & 70.6 & 213 & 77.2 \\
\hline & & Do not know & 14 & 5.4 & 1 & 5.9 & 15 & 5.4 \\
\hline & & Total & 259 & 100.0 & 17 & 100.0 & 276 & 100.0 \\
\hline & Official recognition & Yes (Official) & 153 & 59.1 & 5 & 29.4 & 158 & 57.2 \\
\hline & & No (Mulling) & 106 & 40.9 & 12 & 70.6 & 118 & 42.8 \\
\hline & & Total & 259 & 100.0 & 17 & 100.0 & 276 & 100.0 \\
\hline & Years to become official & Mean & 0.83 & - & 0.67 & - & 0.82 & - \\
\hline & & Std dev & 1.15 & - & 0.82 & - & 1.14 & - \\
\hline \multirow[t]{39}{*}{ Members } & Diversity & Very good & 5 & 2.0 & 1 & 5.9 & 6 & 2.2 \\
\hline & & Fairly good & 108 & 42.2 & 3 & 17.6 & 111 & 40.7 \\
\hline & & Not very good & 131 & 51.2 & 12 & 70.6 & 143 & 52.4 \\
\hline & & Not good at all & 12 & 4.7 & 1 & 5.9 & 13 & 4.8 \\
\hline & & Total & 256 & 100.0 & 17 & 100.0 & 273 & 100.0 \\
\hline & Age of transition initiative members & Less than 30 years old & 9 & 3.8 & 1 & 5.9 & 10 & 3.9 \\
\hline & & Between 30 and 49 years old & 140 & 58.6 & 10 & 58.8 & 150 & 58.6 \\
\hline & & Between 50 and 65 years old & 86 & 36.0 & 4 & 23.5 & 90 & 35.2 \\
\hline & & More than 65 years old & 4 & 1.7 & 2 & 11.8 & 6 & 2.3 \\
\hline & & Total & 239 & 100.0 & 17 & 100.0 & 256 & 100.0 \\
\hline & Preexistence group & Yes & 130 & 50.2 & 11 & 64.7 & 141 & 51.1 \\
\hline & & No & 105 & 40.5 & 5 & 29.4 & 110 & 39.9 \\
\hline & & Do not know & 24 & 9.3 & 1 & 5.9 & 25 & 9.1 \\
\hline & & Total & 259 & 100.0 & 17 & 100.0 & 276 & 100.0 \\
\hline & Founders number & Mean & 10.11 & - & 8.47 & - & 9.71 & - \\
\hline & & Std dev & 14.13 & - & 5.84 & - & 13.04 & - \\
\hline & Occupation of members & Unemployed & 9 & 3.8 & 2 & 11.8 & 11 & 4.3 \\
\hline & & Student & 8 & 3.3 & 2 & 11.8 & 10 & 3.9 \\
\hline & & In employment & 201 & 84.1 & 11 & 64.7 & 212 & 82.8 \\
\hline & & Pensioner & 21 & 8.8 & 2 & 11.8 & 23 & 9.0 \\
\hline & & Total & 239 & 100.0 & 17 & 100.0 & 256 & 100.0 \\
\hline & Age of steering group members & Less than 30 years old & 6 & 2.9 & 1 & 6.7 & 7 & 3.2 \\
\hline & & Between 30 and 49 years old & 92 & 44.4 & 7 & 46.7 & 99 & 44.6 \\
\hline & & Between 50 and 65 years old & 99 & 47.8 & 6 & 40.0 & 105 & 47.3 \\
\hline & & More than 65 years old & 10 & 4.8 & 1 & 6.7 & 11 & 5.0 \\
\hline & & Total & 207 & 100.0 & 15 & 100.0 & 222 & 100.0 \\
\hline & Education of steering group members & No qualification & 5 & 13.2 & 0 & 0.0 & 5 & 12.2 \\
\hline & & Qualification below degree level & 17 & 44.7 & 1 & 33.0 & 18 & 43.9 \\
\hline & & Degree level or above & 2 & 5.3 & 0 & 0.0 & 2 & 4.9 \\
\hline & & Do not know & 14 & 36.8 & 2 & 66.0 & 16 & 39.0 \\
\hline & & Total & 38 & 100.0 & 3 & 100.0 & 41 & 100.0 \\
\hline & Transition training (people) & Mean & 3.03 & - & 2.2 & - & 2.98 & - \\
\hline & & Std dev & 9.82 & - & 1.32 & - & 9.49 & - \\
\hline & Transition training ratio & Mean & 0.42 & - & 0.77 & - & 0.45 & - \\
\hline & & Std dev & 1.5 & - & 0.67 & - & 1.47 & - \\
\hline & Permaculture training (people) & Mean & 2.18 & - & 3.07 & - & 2.24 & - \\
\hline & & Std dev & 2.03 & - & 1.83 & - & 2.02 & - \\
\hline & Permaculture training ratio & Mean & 0.31 & - & 1.01 & - & 0.36 & - \\
\hline & & Std dev & 0.27 & - & 0.97 & - & 0.4 & - \\
\hline
\end{tabular}




\subsubsection{Organisation}

Table 5 shows a summary of the variables associated with the factors organisation and resources. The majority of transition initiatives had a steering group, although the number of steering group members varied markedly within and between the two subgroups of active and non-active transition initiatives. The transition initiatives usually (94\% of cases) did not rely on paid staff, but on voluntary work. $97 \%$ of transition initiatives did engage in some form of recruitment of new members (e.g. online or personal contacts, or social events) (Table A.5 in Electronic Supplementary Materials). The majority of active transition initiatives engaged in both internal and external communication and used a diverse set of tools which included a website or blog, social network pages and printed materials. Non-active transition initiatives, before being discontinued, had shown lower levels of engagement in internal and external communication than active transition initiatives (Table A.5 in Electronic Supplementary Materials).

The majority of transition initiatives claimed no political ideology, but in a minority of cases alternative ideologies that refer to ecocentric (e.g. Gaia) or egalitarian worldviews (Douglas and Wildawsky, 1983) were mentioned. Conflicts were, in general, minor and resolved. 49 transition initiatives had had no significant conflict. Reasons for conflicts were i) strategy, direction and priorities of the transition initiative (55 transition initiatives), ii) decision-making, responsibilities or internal management (including time management and leadership) (36 transition initiatives), iii) issues in a specific project (e.g. how to develop an activity) (25 transition initiatives), iv) personalities (9 transition initiatives), and v) communication with other actors (how to do it and what message to communicate) (7 transition initiatives). The vastly predominant strategy for conflict resolution was based on discussion, mediation and consensus-building, which either followed a formal or a more spontaneous protocol, but in several cases (10 transition initiatives) one or more persons left the group after the conflict (not shown in table).

\subsubsection{Resources}

A certain diversity was observed regarding the proportion of external funding, whereby about $60 \%$ of the transition initiatives had developed forms of fundraising that included one or more of the following: grant applications, lotteries, public or private sponsorship, fundraising events, or the sale of self-produced goods. The most frequent sources of external funding were local authorities (49 transition initiatives), donations and sponsorships (e.g. from foundations, banks or other private organisations) (46 transition initiatives), and fundraising through events and sale of self-produced products (35 transition initiatives). There was high variation in terms of time dedicated to transition initiative activities on a weekly basis by the steering group members, which on average amounted to 27 hours per group. Regarding infrastructure, the majority of transition initiatives had access to a meeting room or office and to computing facilities (including printer and video reproduction equipment) (not shown in table). Transition initiatives that did not have access to external funds usually funded their activities through the members' own voluntary monetary contribution.

In summary, the most marked differences observed between active and non-active transition initiatives with respect to organisation and resources were noted in the number of steering group members, organisation of subgroups, the proportion of external funds and the time dedicated by the steering group members to the transition initiatives. 
Table 5. Summary of organisation and resource variables (valid \% shown).

\begin{tabular}{|c|c|c|c|c|c|c|c|c|}
\hline \multirow[b]{2}{*}{ Factor } & \multirow[b]{2}{*}{ Variable } & & \multicolumn{2}{|c|}{$\begin{array}{c}\text { Active } \\
\text { transition } \\
\text { initiatives }\end{array}$} & \multicolumn{2}{|c|}{$\begin{array}{l}\text { Non-active } \\
\text { transition } \\
\text { initiatives }\end{array}$} & \multicolumn{2}{|c|}{\begin{tabular}{|c} 
All \\
transition \\
initiatives
\end{tabular}} \\
\hline & & & $\mathbf{N}$ & $\%$ & $\mathbf{N}$ & $\%$ & $\mathbf{N}$ & $\%$ \\
\hline \multirow[t]{15}{*}{ Organisation } & Steering group & Yes & 215 & 83 & 15 & 88.2 & 230 & 83.3 \\
\hline & & No & 44 & 17.0 & 2 & 11.8 & 46 & 16.7 \\
\hline & & Total & 259 & 100.0 & 17 & 100.0 & 276 & 100.0 \\
\hline & $\begin{array}{l}\text { Number of steering } \\
\text { group members }\end{array}$ & Mean & 9.77 & & 4 & - & 9.4 & - \\
\hline & & Std dev & 18.80 & - & 2.39 & - & 18.25 & - \\
\hline & Paid staff & All members of the steering group are paid staff ( $100 \%)$ & 2 & 0.9 & 0 & 0.0 & 2 & 0.9 \\
\hline & & Most of the members of the steering group are paid staff (about 75\%) & 1 & 0.5 & 0 & 0.0 & 1 & 0.4 \\
\hline & & There are an equal number of paid staff and volunteers in the steering group & 0 & 0.0 & 0 & 0.0 & 0 & 0.0 \\
\hline & & Some members of the steering group are paid staff (about 25\%) & 9 & 4.2 & 0 & 0.0 & 9 & 3.9 \\
\hline & & None of the members of the steering group are paid staff $(0 \%)$ & 203 & 94.0 & 15 & 100.0 & 218 & 94.4 \\
\hline & & Do not know & 1 & 0.5 & 0 & 0.0 & 1 & 0.4 \\
\hline & & Total & 216 & 100.0 & 15 & 100.0 & 231 & 100.0 \\
\hline & Subgroups & Yes & 142 & 56.1 & 6 & 35.3 & 148 & 54.8 \\
\hline & & No & 111 & 43.9 & 11 & 64.7 & 122 & 45.2 \\
\hline & & Total & 253 & 100.0 & 17 & 100.0 & 270 & 100.0 \\
\hline \multirow[t]{9}{*}{ Resources } & $\begin{array}{l}\text { Proportion of external } \\
\text { funding }\end{array}$ & All funds were external (100\%) & 32 & 13.6 & 0 & 0.0 & 32 & 12.8 \\
\hline & & Most of the funds were external (about 75\%) & 57 & 24.2 & 2 & 14.3 & 59 & 23.6 \\
\hline & & There were equal proportions of external and internal funds & 25 & 10.6 & 0 & 0.0 & 25 & 10 \\
\hline & & Little funds were external (about 25\%) & 26 & 11.0 & 2 & 14.3 & 28 & 11.2 \\
\hline & & No funds were external (0\%) & 90 & 38.1 & 9 & 64.3 & 99 & 39.6 \\
\hline & & Do not know & 6 & 2.5 & 1 & 7.1 & 7 & 2.8 \\
\hline & & Total & 236 & 100 & 14 & 100 & 250 & 100 \\
\hline & $\begin{array}{l}\text { Time dedicated by } \\
\text { steering group (hours } \\
\text { per week) }\end{array}$ & Mean & 27.94 & - & 16.88 & - & 27.36 & - \\
\hline & & Std dev & 23.28 & - & 11.24 & - & 22.92 & - \\
\hline
\end{tabular}

\subsubsection{Context}

Table 6 shows a summary of the variables associated with the factor context. The majority of transition initiatives had established forms of cooperation or partnership with local authorities, local media, local business, non-governmental organisations (NGOs) and other grassroots or activist groups, and other transition initiatives.

The majority of transition initiatives also considered to be perceived positively by several local actors including local authorities, local business and media, social enterprises, NGOs, other transition initiatives and regional or national Transition Network hubs. Nevertheless, a significant number of transition initiatives did not have a clear idea of how favourably the transition initiative was perceived (answer: 'Do not know'). By and large, active transition initiatives showed higher rates of cooperation and partnership with other local actors, and a more positive perception of the context (i.e. how favourably different actors were towards the transition initiative). 
Feola, G., Nunes, J.R. 2014. Success and failure of Grassroots Innovations for addressing climate change: the case of the Transition Movement. Global Environmental Change 24, 232-250.

Table 6. Summary of context variables (valid \% shown).

\begin{tabular}{|c|c|c|c|c|c|c|c|}
\hline \multirow{2}{*}{ Variables } & & \multicolumn{2}{|c|}{ Active transition initiatives } & \multicolumn{2}{|c|}{ Non-active transition initiatives } & \multicolumn{2}{|c|}{ All transition initiatives } \\
\hline & & $\mathbf{N}$ & $\%$ & $\mathbf{N}$ & $\%$ & $\mathbf{N}$ & $\%$ \\
\hline Cooperation with local authorities & Yes, currently & 160 & 66.4 & - & - & - & - \\
\hline & Yes, in the past & 39 & 16.2 & 10 & 62.5 & 49 & 19.1 \\
\hline & No & 42 & 17.4 & 5 & 31.3 & 47 & 18.3 \\
\hline & Do not know & 0 & 0.0 & 1 & 6.3 & 1 & 0.4 \\
\hline & Total & 241 & 100.0 & 16 & 100.0 & 257 & 100.0 \\
\hline Cooperation with mass media & Yes, currently & 144 & 59.8 & - & - & - & - \\
\hline & Yes, in the past & 52 & 21.6 & 12 & 75.0 & 64 & 24.9 \\
\hline & No & 45 & 18.7 & 2 & 12.5 & 47 & 18.3 \\
\hline & Do not know & 0 & 0.0 & 2 & 12.5 & 2 & 0.8 \\
\hline & Total & 241 & 100.0 & 16 & 100.0 & 257 & 100.0 \\
\hline Cooperation with local business & Yes, currently & 187 & 77.6 & - & - & - & - \\
\hline & Yes, in the past & 33 & 13.7 & 8 & 50.0 & 41 & 16.0 \\
\hline & No & 19 & 7.9 & 6 & 37.5 & 25 & 9.7 \\
\hline & Do not know & 2 & 0.8 & 2 & 12.5 & 4 & 1.6 \\
\hline & Total & 241 & 100.0 & 16 & 100.0 & 257 & 100.0 \\
\hline Cooperation with social enterprises & Yes, currently & 108 & 44.8 & - & - & - & - \\
\hline & Yes, in the past & 30 & 12.4 & 6 & 37.5 & 36 & 14.0 \\
\hline & No & 89 & 36.9 & 8 & 50.0 & 97 & 37.7 \\
\hline & Do not know & 14 & 5.8 & 2 & 12.5 & 16 & 6.2 \\
\hline & Total & 241 & 100.0 & 16 & 100.0 & 257 & 100.0 \\
\hline Cooperation with NGOs & Yes, currently & 187 & 77.6 & - & - & & - \\
\hline & Yes, in the past & 33 & 13.7 & 10 & 62.5 & 43 & 16.7 \\
\hline & No & 19 & 7.9 & 5 & 31.3 & 24 & 9.3 \\
\hline & Do not know & 2 & 0.8 & 1 & 6.3 & 3 & 1.2 \\
\hline & Total & 241 & 100.0 & 16 & 100.0 & 257 & 100.0 \\
\hline Cooperation with other transition initiatives & Yes, currently & 154 & 63.9 & - & - &  & - \\
\hline & Yes, in the past & 51 & 21.2 & 12 & 75.0 & 63 & 24.5 \\
\hline & No & 34 & 14.1 & 4 & 25.0 & 38 & 14.8 \\
\hline & Do not know & 2 & 0.8 & 0 & 0.0 & 2 & 0.8 \\
\hline & Total & 241 & 100.0 & 16 & 100.0 & 257 & 100.0 \\
\hline Cooperation with regional/national Transition Network hub & Yes, currently & 109 & 45.2 & - & - & - & - \\
\hline & Yes, in the past & 48 & 19.9 & 7 & 43.8 & 55 & 21.4 \\
\hline & No & 76 & 31.5 & 9 & 56.3 & 85 & 33.1 \\
\hline & Do not know & 8 & 3.3 & 0 & 0.0 & 8 & 3.1 \\
\hline & Total & 241 & 100.0 & 16 & 100.0 & 257 & 100.0 \\
\hline Cooperation with educational institutions & Yes, currently & 94 & 39.0 & - & - & - & - \\
\hline & Yes, in the past & 37 & 15.4 & 6 & 37.5 & 43 & 16.7 \\
\hline & No & 105 & 43.6 & 8 & 50.0 & 113 & 44.0 \\
\hline & Do not know & 5 & 2.1 & 2 & 12.5 & 7 & 2.7 \\
\hline & Total & 241 & 100.0 & 16 & 100.0 & 257 & 100.0 \\
\hline Favourable context: local authorities & Agree & 163 & 67.6 & 6 & 37.5 & 169 & 65.8 \\
\hline & Neither agree nor disagree & 41 & 17.0 & 6 & 37.5 & 47 & 18.3 \\
\hline & Disagree & 16 & 6.6 & 0 & 0.0 & 16 & 6.2 \\
\hline & Do not know & 21 & 8.7 & 4 & 25.0 & 25 & 9.7 \\
\hline & Total & 241 & 100.0 & 16 & 100.0 & 257 & 100.0 \\
\hline Favourable context: local business & Agree & 158 & 65.6 & 8 & 50.0 & 166 & 64.6 \\
\hline & Neither agree nor disagree & 54 & 22.4 & 7 & 43.8 & 61 & 23.7 \\
\hline & Disagree & 9 & 3.7 & 0 & 0.0 & 9 & 3.5 \\
\hline & Do not know & 20 & 8.3 & 1 & 6.3 & 21 & 8.2 \\
\hline & Total & 241 & 100.0 & 16 & 100.0 & 257 & 100.0 \\
\hline Favourable context: mass media & Agree & 66 & 27.4 & 3 & 18.8 & 69 & 26.8 \\
\hline & Neither agree nor disagree & 112 & 46.5 & 9 & 56.3 & 121 & 47.1 \\
\hline & Disagree & 12 & 5.0 & 1 & 6.3 & 13 & 5.1 \\
\hline & Do not know & 51 & 21.2 & 3 & 18.8 & 54 & 21.0 \\
\hline & Total & 241 & 100.0 & 16 & 100.0 & 257 & 100.0 \\
\hline Favourable context: social enterprises & Agree & 127 & 52.7 & 4 & 25.0 & 131 & 51.0 \\
\hline & Neither agree nor disagree & 50 & 20.7 & 7 & 43.8 & 57 & 22.2 \\
\hline & Disagree & 2 & 0.8 & 1 & 6.3 & 3 & 1.2 \\
\hline & Do not know & 62 & 25.7 & 4 & 25.0 & 66 & 25.7 \\
\hline & Total & 241 & 100.0 & 16 & 100.0 & 257 & 100.0 \\
\hline Favourable context: NGOs & Agree & 198 & 82.2 & 9 & 56.3 & 207 & 80.5 \\
\hline & Neither agree nor disagree & 29 & 12.0 & 4 & 25.0 & 33 & 12.8 \\
\hline & Disagree & 3 & 1.2 & 2 & 12.5 & 5 & 1.9 \\
\hline & Do not know & 11 & 4.6 & 1 & 6.3 & 12 & 4.7 \\
\hline & Total & 241 & 100.0 & 16 & 100.0 & 257 & 100.0 \\
\hline Favourable context: other transition initiatives & Agree & 195 & 80.9 & 10 & 62.5 & 205 & 79.8 \\
\hline & Neither agree nor disagree & 19 & 7.9 & 3 & 18.8 & 22 & 8.6 \\
\hline & Disagree & 1 & 0.4 & 2 & 12.5 & 3 & 1.2 \\
\hline & Do not know & 26 & 10.8 & 1 & 6.3 & 27 & 10.5 \\
\hline & Total & 241 & 100.0 & 16 & 100.0 & 257 & 100.0 \\
\hline Favourable context: regional/national Transition Network hub & Agree & 133 & 55.2 & 8 & 50.0 & 141 & 54.9 \\
\hline & Neither agree nor disagree & 41 & 17.0 & 5 & 31.3 & 46 & 17.9 \\
\hline & Disagree & 2 & 0.8 & 0 & 0.0 & 2 & 0.8 \\
\hline & Do not know & 65 & 27.0 & 3 & 18.8 & 68 & 26.5 \\
\hline & Total & 241 & 100.0 & 16 & 100.0 & 257 & 100.0 \\
\hline Favourable context: educational institutions & Agree & 102 & 42.3 & 6 & 37.5 & 108 & 42.0 \\
\hline & Neither agree nor disagree & 57 & 23.7 & 5 & 31.3 & 62 & 24.1 \\
\hline & Disagree & 6 & 2.5 & 0 & 0.0 & 6 & 2.3 \\
\hline & Do not know & 76 & 31.5 & 5 & 31.3 & 81 & 31.5 \\
\hline & Total & 241 & 100.0 & 16 & 100.0 & 257 & 100.0 \\
\hline
\end{tabular}




\subsection{Factors that contributed to the success of transition initiatives}

We explored the contribution of the explanatory factors to the success of transition initiatives (section 3.2) by means of correlation analysis (categorical explanatory factors) and comparison of means (numerical explanatory factors). Table 7 shows the correlation for active transition initiatives between single categorical independent variables and the dependent variable success, which was transformed for this purpose into a bimodal variable (i.e. very or fairly successful, not very or not successful at all). This exploratory analysis allowed a first identification of the variables that most significantly influenced the level of transition initiative success. Table 8 compares the means for numerical independent variables between the two groups, i.e. of very or fairly successful and of not very or not at all successful transition initiatives. Tables 7 and 8 show that several variables significantly correlate with the level of transition initiative success, but the estimated effect size was low for all explanatory factors, indicating low magnitude of the effects of these variables on the success of grassroots innovations.

Table 7. Pearson Chi-Square test and Cramer's $\mathrm{V}$ measure of correlation between explanatory factors and success of a transition initiative.

\begin{tabular}{|c|c|c|c|c|c|}
\hline \multirow[b]{2}{*}{ Group } & \multirow[b]{2}{*}{ Variable } & \multirow[b]{2}{*}{$\mathbf{N}$} & \multicolumn{3}{|c|}{ Cramer's V } \\
\hline & & & Pearson's Chi-Square & (effect size) & p \\
\hline \multirow[t]{5}{*}{ Transition initiative characteristics } & Type of transition initiative & 259 & 4.712 & 0.135 & $0.095^{*}$ \\
\hline & Legal form & 249 & 8.575 & 0.186 & $0.003 * * *$ \\
\hline & First theme addressed & 234 & 17.872 & 0.276 & 0.162 \\
\hline & Official recognition & 259 & 12.549 & 0.220 & $0.000 * * *$ \\
\hline & Country \# & 259 & 10.212 & 0.212 & 0.250 \\
\hline \multirow[t]{5}{*}{ Members } & Age of transition initiative members & 239 & 3.534 & 0.112 & 0.316 \\
\hline & Age of steering group members & 207 & 4.962 & 0.155 & 0.175 \\
\hline & Education of steering group members & 24 & 8.291 & 0.588 & $0.016^{* *}$ \\
\hline & Diversity & 256 & 14.528 & 0.238 & $0.002 * * *$ \\
\hline & Pre-existence group & 235 & 0.312 & 0.036 & 0.577 \\
\hline \multirow[t]{7}{*}{ Organisation } & Steering group & 259 & 8.233 & 0.117 & $0.004^{* * *}$ \\
\hline & Subgroups & 253 & 6.578 & 0.161 & $0.010 * *$ \\
\hline & Paid staff & 215 & 3.627 & 0.130 & 0.305 \\
\hline & Conflict resolution & 166 & 0.526 & 0.056 & 0.468 \\
\hline & Political orientation & 256 & 0.081 & 0.018 & 0.775 \\
\hline & Recruitment & 259 & 22.793 & 0.297 & $0.000 * * *$ \\
\hline & Web & 253 & 1.938 & 0.088 & 0.164 \\
\hline \multirow[t]{6}{*}{ Resources } & Proportion of external funding & 230 & 5.59 & 0.156 & $0.018 * *$ \\
\hline & Meeting room & 225 & 2.273 & 0.101 & 0.132 \\
\hline & Office & 236 & 1.666 & 0.086 & 0.197 \\
\hline & PC & 236 & 1.697 & 0.086 & 0.193 \\
\hline & Printer & 236 & 0.812 & 0.060 & 0.367 \\
\hline & Video reproduction & 236 & 0.789 & 0.059 & 0.374 \\
\hline \multirow[t]{17}{*}{ Context } & Participatory democracy & 182 & 1.473 & 0.090 & 0.225 \\
\hline & Cooperation with local authorities & 241 & 12.405 & 0.227 & $0.002 * * *$ \\
\hline & Cooperation with mass media & 241 & 11.805 & 0.221 & $0.003 * * *$ \\
\hline & Cooperation with local business & 239 & 23.598 & 0.314 & $0.000 * * *$ \\
\hline & Cooperation with social enterprises & 227 & 14.297 & 0.251 & $0.001 * * *$ \\
\hline & Cooperation with NGOs & 239 & 0.527 & 0.049 & 0.753 \\
\hline & Cooperation with other transition initiatives & 239 & 10.757 & 0.212 & $0.005 * * *$ \\
\hline & Cooperation with regional/national Transition Network hut & 233 & 5.818 & 0.158 & $0.055 *$ \\
\hline & Cooperation with educational institutions & 236 & 2.552 & 0.104 & 0.279 \\
\hline & Favourable context: local authorities & 220 & 13.754 & 0.250 & $0.008 * * *$ \\
\hline & Favourable context: mass media & 221 & 15.092 & 0.261 & $0.005^{* * *}$ \\
\hline & Favourable context: local business & 190 & 7.342 & 0.197 & 0.119 \\
\hline & Favourable context: social enterprises & 179 & 9.954 & 0.236 & $0.019 * *$ \\
\hline & Favourable context: NGOs & 230 & 8.639 & 0.194 & $0.034 * *$ \\
\hline & Favourable context: other transition initiatives & 215 & 14.992 & 0.264 & $0.002 * * *$ \\
\hline & Favourable context: regional/national Transition Network & 176 & 15.879 & 0.300 & $0.003 * * *$ \\
\hline & Favourable context: educational institutions & 165 & 13.245 & 0.283 & $0.010 * *$ \\
\hline
\end{tabular}

* Significant at 10\% level; ** Significant at 5\% level; ***Significant at 1\% level; \# Chi-Square calculated only considering countries with $\mathrm{N}>5$. 
Table 8. Mann-Whitney $U$ test and estimated effect size for numeric independent variables by level of success (bimodal).

\begin{tabular}{|c|c|c|c|c|c|}
\hline \multirow{2}{*}{\multicolumn{2}{|c|}{$\begin{array}{ll}\text { Group } & \text { Variable } \\
\text { Transition initiati Years to become official }\end{array}$}} & \multicolumn{2}{|c|}{ N Mann-Whitney U test Z } & \multicolumn{2}{|c|}{$p$ effect size } \\
\hline & & 132 & 2.046 & 0.041 & $0.18 * *$ \\
\hline \multirow[t]{5}{*}{ Members } & Transition training & 204 & 1.488 & 0.080 & $0.10^{*}$ \\
\hline & Transition training ratio & 193 & 0.264 & 0.493 & 0.02 \\
\hline & Permaculture training & 199 & 2.036 & 0.042 & $0.14 * *$ \\
\hline & Permaculture training ratio & 188 & 0.577 & 0.502 & 0.04 \\
\hline & Founders number & 247 & 2.276 & 0.023 & $0.14^{* *}$ \\
\hline Organisation & Number of steering group members & 203 & 2.607 & 0.009 & $0.18^{* * *}$ \\
\hline Resources & Time dedicated by steering group & 146 & 0.988 & 0.323 & 0.08 \\
\hline
\end{tabular}

* Significant at $10 \%$ level; ** Significant at $5 \%$ level; ***Significant at $1 \%$ level.

We tested for correlation among the variables associated with the factor context, i.e. cooperation with other actors and favourable context. As expected, significant correlations were observed (Pearson correlation between 0.300 and 0.650 ): transition initiatives who cooperate with other actors tend to consider these actors positively, or vice versa (not shown in table).

Because cities are considered to be more socially diverse than rural/towns, we also analysed the correlation of diversity and success, controlling for the type of transition initiative. In effect, we observed that diversity correlates significantly with success for city/urban transition initiatives but not for other types of transition initiatives, suggesting that the location (i.e. city/urban versus rural/town) influences directly the degree to which a transition initiative represents diversity in its community which, in turn, influences transition initiative success (not shown in table).

Finally, because several transition initiative characteristics are more frequent among official transition initiatives, we analysed the correlation of subgroups, steering committee, legal form with success controlling for official. transition initiatives that obtain official recognition by the Transition Network tend to be organised in subgroups, have a steering group and constitute a formal organisation more than mulling transition initiatives. We observed that being equal official, steering committee significantly correlates with success for official but not for mulling transition initiatives, whereas subgroups and legal form significantly correlate with success for mulling but not for official transition initiatives, confirming that the 'official' status influences directly other key variables (transition initiative characteristics), e.g. subgroups, steering committee, legal form, which, in turn influence transition initiative success (not shown in table).

\subsection{A typology of transition initiatives}

To account for the influence of multiple variables and with the aim to identify common patterns of transition initiative success and failure, in the last stage of our analysis we built clusters based on the variables that had resulted in being significantly correlated with success (subjective, bimodal) (Tables 7 and 8). Following a two-step cluster procedure we identified three clusters of active transition initiatives, in addition to which we analysed non-active transition initiatives as a pre-identified cluster. Table 9 shows a summary of the descriptive statistics for dependent and independent variables for the four clusters. These clusters correspond to four transition initiative types each of which is characterised by a level of success and a particular combination of factors.

Cluster 1. Cluster 1 groups transition initiatives that tended to be very or fairly successful, and to be located in villages, rural areas or towns. In comparison with transition initiatives in other clusters, these transition initiatives were mostly initiated by a larger group of founders. They had existed on average for about four years. While these transition initiatives were not necessarily officially recognised by the Transition Network, those that were officially recognised took one year on average from the foundation year to recognition and followed approximately 10 'steps to transition'. They tended to have a steering group with members trained in Transition and/or permaculture, and to be 
organised in, for example, thematic or project-based subgroups. The steering group tended to be larger and to invest a higher number of hours than transition initiatives in other clusters. transition initiatives in this cluster tended to get at least part of their funds from external sources and were very well connected to other actors in the local context, which were generally perceived as favourable towards the transition initiatives.

Cluster 2. Cluster 2 groups transition initiatives that were mostly fairly successful. They tended to be officially recognised by the Transition Network and to have taken almost one year to be recognised since their foundation and followed approximately 8.5 'steps to transition'. They had existed on average for four years, and were founded by relatively few people originally, but were characterised, in comparison with transition initiatives in other clusters, by a large steering group of trained members. They were not necessarily organised in subgroups and usually not constituted in a legal form. They tended to rely on some proportion of external funds and to be located in a favourable context (local authorities, mass media, other NGOs, other transition initiatives, regional or national Transition Network hubs), although this did not necessarily translate into cooperation with other local actors. Cluster 2 transition initiatives tended to cooperate with local authorities and other transition initiatives, but less with other actors. They were more frequently located in the United Kingdom than transition initiatives in other clusters.

Cluster 3. Cluster 3 groups transition initiatives that tended to be not very successful or not at all successful. These transition initiatives tended not to be constituted in a legal form and to be mulling rather than officially recognised. When they were officially recognised by the Transition Network, they tended to have reached recognition rather quickly (i.e. in a few months). They were relatively young (less than three years) and have on average undertaken six to seven 'steps to transition'. These transition initiatives tended not to mirror the diversity of their community very well. If they had a steering group, this tended to be a small group of people of which only few had attended transition or permaculture training. They usually could not rely on external funds and were weakly connected with other actors in their local context, which overall was perceived to disadvantage transition initiatives. In particular, these transition initiatives tended to be more disconnected than those in other clusters from regional or national Transition Network hubs and to have a poorer knowledge of their own context. Finally, they tended to be less concentrated in the United Kingdom than transition initiatives in other clusters.

Cluster 4. These non-active transition initiatives, before being discontinued, shared several characteristics with Cluster 3 transition initiatives. In particular, they achieved similar levels of success, tended to be mulling and not constituted in legal form, to be relatively young (3.6 years) have undertaken six 'steps to transition', and to represent the diversity of their community poorly, also being more frequently located in an urban context. They also tended to be disconnected from the regional and national Transition Network hubs, but, differently from Cluster 3 transition initiatives, they had shown some level of cooperation with other actors in their local context (local authorities, mass media and other transition initiatives). Non-active transition initiatives were usually guided by trained steering group members, but the steering groups tended to be small and to have little time to dedicate to the transition initiative. 
Table 9. Descriptive characteristics of key variables for the four clusters of transition initiatives (part \).

\begin{tabular}{|c|c|c|c|c|c|c|c|c|c|c|}
\hline \multirow[b]{2}{*}{ Variable group } & \multirow[b]{2}{*}{ Variable } & & \multicolumn{2}{|c|}{ Cluster 1} & \multicolumn{2}{|c|}{ Cluster 2} & \multicolumn{2}{|c|}{ Cluster 3} & \multicolumn{2}{|c|}{$\begin{array}{l}\text { Non-active } \\
\text { transition } \\
\text { initiatives }\end{array}$} \\
\hline & & & $\mathbf{N}$ & $\%$ & $\mathbf{N}$ & $\%$ & $\mathbf{N}$ & $\%$ & $\mathbf{N}$ & $\%$ \\
\hline & Success & Very successful & 19 & 27.1 & 7 & 8.4 & 3 & 4.9 & 0 & 0.0 \\
\hline & & Fairly Successful & 48 & 68.6 & 62 & 74.7 & 32 & 52.5 & 3 & 17.6 \\
\hline & & Not very successful & 3 & 4.3 & 13 & 15.7 & 25 & 41.0 & 9 & 52.9 \\
\hline & & Not successful at all & 0 & 0.0 & 1 & 1.2 & 1 & 1.6 & 5 & 29.4 \\
\hline & Success (bimodal) & Very or fairly successful & 67 & 91.3 & 69 & 83.1 & 33 & 55.9 & 3 & 17.6 \\
\hline & & Not very or not successful at all & 3 & 8.7 & 14 & 16.9 & 26 & 44.1 & 14 & 82.4 \\
\hline \multirow{9}{*}{$\begin{array}{l}\text { Transition Initiative } \\
\text { characteristics }\end{array}$} & Type of transition initiative & Urban/City & 23 & 32.9 & 29 & 34.9 & 19 & 31.1 & 9 & 52.9 \\
\hline & & Village/Rural/Forest/Island & 16 & 22.9 & 17 & 20.5 & 21 & 34.4 & 3 & 17.7 \\
\hline & & Town & 31 & 44.3 & 37 & 44.6 & 21 & 34.4 & 5 & 29.4 \\
\hline & Legal status & Yes & 34 & 48.6 & 24 & 28.9 & 15 & 24.6 & 4 & 25.0 \\
\hline & & No & 36 & 51.4 & 59 & 71.1 & 46 & 75.4 & 12 & 75.0 \\
\hline & Official recognition & Yes & 44 & 62.9 & 68 & 81.9 & 14 & 23.0 & 5 & 29.4 \\
\hline & & No ('mulling') & 26 & 37.1 & 15 & 18.1 & 47 & 77.0 & 12 & 70.6 \\
\hline & Years to become official (years) & Mean & 1.01 & - & 0.83 & - & 0.38 & - & 0.67 & - \\
\hline & & Std dev & 1.57 & - & 1 & - & 0.51 & - & 0.82 & - \\
\hline \multirow[t]{13}{*}{ Members } & Education of steering group members & No qualification & 1 & 8.3 & 3 & 23.1 & 1 & 12.5 & 0 & 0.0 \\
\hline & & Qualification below degree leve & 7 & 58.3 & 5 & 38.5 & 2 & 25.0 & 1 & 33.3 \\
\hline & & Degree level or above & 0 & 0.0 & 1 & 7.7 & 1 & 12.5 & 0 & 0.0 \\
\hline & Diversity & Very good & 3 & 4.3 & 0 & 0.0 & 1 & 1.6 & 1 & 5.9 \\
\hline & & Fairly good & 42 & 60.0 & 30 & 36.1 & 25 & 41.0 & 3 & 17.6 \\
\hline & & Not very good & 24 & 34.3 & 49 & 59.0 & 32 & 52.5 & 12 & 70.6 \\
\hline & & Not good at all & 1 & 1.4 & 4 & 4.8 & 3 & 4.9 & 1 & 5.9 \\
\hline & Transition training (people) & Mean & 2.6 & - & 5.08 & - & 0.92 & - & 2.2 & - \\
\hline & & Std dev & 2.7 & - & 16.22 & - & 1.18 & - & 1.32 & - \\
\hline & Permaculture training (people) & Mean & 2.84 & - & 2.03 & - & 1.64 & - & 3.07 & - \\
\hline & & Std dev & 2.55 & - & 1.77 & - & 1.66 & - & 1.83 & - \\
\hline & Founders number (people) & Mean & 12.39 & - & 7.49 & - & 11.52 & - & 8.47 & - \\
\hline & & Std dev & 17.19 & - & 5.57 & - & 19.69 & - & 5.84 & - \\
\hline \multirow[t]{8}{*}{ Organisation } & Steering group & Yes & 65 & 92.9 & 72 & 86.7 & 40 & 65.6 & 15 & 88.2 \\
\hline & & No & 5 & 7.1 & 11 & 13.3 & 21 & 34.4 & 2 & 11.8 \\
\hline & $\begin{array}{l}\text { Number of steering group members } \\
\text { (people) }\end{array}$ & Mean & 13.05 & - & 8.03 & - & 6.63 & - & 4 & - \\
\hline & & Std dev & 30.82 & - & 5.25 & - & 3.65 & - & 2.39 & - \\
\hline & Subgroups & Yes & 53 & 75.7 & 47 & 56.6 & 21 & 34.4 & 6 & 35.3 \\
\hline & & No & 17 & 24.3 & 36 & 43.4 & 41 & 65.6 & 11 & 64.7 \\
\hline & Recruitment & Yes & 68 & 97.1 & 82 & 98.8 & 58 & 95.1 & 15 & 100.0 \\
\hline & & No & 2 & 2.9 & 1 & 1.2 & 3 & 4.9 & 0 & 0.0 \\
\hline \multirow[t]{4}{*}{ Resources } & Proportion of external funding & No external funding & 15 & 21.4 & 27 & 32.5 & 43 & 70.5 & 9 & 28.6 \\
\hline & & $25 \%$ to $100 \%$ external funding & 55 & 78.6 & 56 & 67.5 & 18 & 29.5 & 4 & 64.3 \\
\hline & $\begin{array}{l}\text { Time dedicated by steering group } \\
\text { (hours per week) }\end{array}$ & Mean & 34.37 & - & 24.6 & - & 27.85 & - & 16.88 & - \\
\hline & & Standard deviation & 29.18 & - & 16.04 & - & 22.37 & - & 11.24 & - \\
\hline
\end{tabular}


Feola, G., Nunes, J.R. 2014. Success and failure of Grassroots Innovations for addressing climate change: the case of the Transition Movement. Global Environmental Change 24, 232-250.

Table 9. Descriptive characteristics of key variables for the four clusters of transition initiatives (part 2).

\begin{tabular}{|c|c|c|c|c|c|c|c|c|c|c|}
\hline \multirow[b]{2}{*}{ Variable group } & \multirow[b]{2}{*}{ Variable } & & \multicolumn{2}{|c|}{ Cluster 1} & \multicolumn{2}{|c|}{ Cluster 2} & \multicolumn{2}{|c|}{ Cluster 3} & \multicolumn{2}{|c|}{$\begin{array}{l}\text { Non-active } \\
\text { transition } \\
\text { initiatives }\end{array}$} \\
\hline & & & $\mathrm{N}$ & $\%$ & $\mathbf{N}$ & $\%$ & $\mathbf{N}$ & $\%$ & $\mathbf{N}$ & $\%$ \\
\hline \multirow[t]{39}{*}{ Context } & Cooperation with local authorities & Yes, currently & 69 & 98.6 & 55 & 66.3 & 18 & 29.5 & - & - \\
\hline & & Yes, in the past & 0 & 0.0 & 22 & 26.5 & 13 & 21.3 & 10 & 62.5 \\
\hline & & No & 1 & 1.4 & 6 & 7.2 & 30 & 49.2 & 5 & 31.3 \\
\hline & Cooperation with mass media & Yes, currently & 63 & 90.0 & 43 & 51.8 & 21 & 34.4 & - & - \\
\hline & & Yes, in the past & 6 & 8.6 & 29 & 34.9 & 13 & 21.3 & 12 & 75.0 \\
\hline & & No & 1 & 1.4 & 11 & 13.3 & 27 & 44.3 & 2 & 12.5 \\
\hline & Cooperation with local business & Yes, currently & 55 & 78.6 & 34 & 41.0 & 12 & 19.7 & - & \\
\hline & & Yes, in the past & 8 & 11.4 & 22 & 26.5 & 5 & 8.2 & 8 & 50.0 \\
\hline & & No & 7 & 10.0 & 27 & 32.5 & 43 & 70.5 & 6 & 37.5 \\
\hline & Cooperation with social enterprises & Yes, currently & 50 & 71.4 & 33 & 39.8 & 14 & 23.0 & - & - \\
\hline & & Yes, in the past & 6 & 8.6 & 20 & 24.1 & 2 & 3.3 & 6 & 37.5 \\
\hline & & No & 10 & 14.3 & 30 & 36.1 & 41 & 67.2 & 8 & 50.0 \\
\hline & $\begin{array}{l}\text { Cooperation with other transition } \\
\text { initiatives }\end{array}$ & Yes, currently & 62 & 88.6 & 58 & 69.9 & 14 & 23.0 & - & - \\
\hline & & Yes, in the past & 8 & 11.4 & 20 & 24.1 & 19 & 31.1 & 12 & 75.0 \\
\hline & & No & 0 & 0.0 & 5 & 6.0 & 27 & 44.3 & 4 & 25.0 \\
\hline & $\begin{array}{l}\text { Cooperation with regional/national } \\
\text { Transition Network hub }\end{array}$ & Yes, currently & 43 & 61.4 & 39 & 47.0 & 14 & 23.0 & - & - \\
\hline & & Yes, in the past & 16 & 22.9 & 17 & 20.5 & 12 & 19.7 & 7 & 43.8 \\
\hline & & No & 9 & 12.9 & 25 & 30.1 & 34 & 55.7 & 9 & 56.3 \\
\hline & Favourable context: local authorities & Agree & 61 & 87.1 & 60 & 72.3 & 23 & 37.7 & 6 & 37.5 \\
\hline & & Neither agree nor disagree & 5 & 7.1 & 18 & 21.7 & 14 & 23.0 & 6 & 37.5 \\
\hline & & Disagree & 1 & 1.4 & 4 & 4.8 & 9 & 14.8 & 0 & 0.0 \\
\hline & Favourable context: mass media & Agree & 58 & 82.9 & 56 & 67.5 & 27 & 44.6 & 8 & 51.1 \\
\hline & & Neither agree nor disagree & 9 & 12.9 & 21 & 25.3 & 19 & 31.1 & 7 & 43.8 \\
\hline & & Disagree & 1 & 1.4 & 5 & 6.0 & 2 & 3.3 & 0 & 0.0 \\
\hline & Favourable context: social enterprises & Agree & 55 & 78.8 & 43 & 51.8 & 17 & 27.9 & 4 & 25.0 \\
\hline & & Neither agree nor disagree & 1 & 1.4 & 28 & 33.7 & 14 & 23.0 & 7 & 43.8 \\
\hline & & Disagree & 0 & 0.0 & 2 & 2.4 & 0 & 0.0 & 1 & 6.3 \\
\hline & Favourable context: NGOs & Agree & 63 & 90.0 & 64 & 77.1 & 51 & 83.6 & 9 & 56.3 \\
\hline & & Neither agree nor disagree & 3 & 4.3 & 14 & 16.9 & 7 & 11.5 & 4 & 25.0 \\
\hline & & Disagree & 0 & 0.0 & 2 & 2.4 & 1 & 1.6 & 2 & 12.5 \\
\hline & $\begin{array}{l}\text { Favourable context: other transition } \\
\text { initiatives }\end{array}$ & Agree & 65 & 92.9 & 75 & 90.4 & 37 & 57.3 & 10 & 52.5 \\
\hline & & Neither agree nor disagree & 1 & 5.7 & 6 & 7.2 & 8 & 13.1 & 3 & 18.8 \\
\hline & & Disagree & 0 & 0.0 & 2 & 2.4 & 1 & 1.6 & 2 & 12.5 \\
\hline & $\begin{array}{l}\text { Favourable context: regional/national } \\
\text { Transition Network hub }\end{array}$ & Agree & 47 & 67.1 & 49 & 59.0 & 24 & 39.4 & 8 & 50.0 \\
\hline & & Neither agree nor disagree & 4 & 11.4 & 23 & 27.7 & 9 & 14.8 & 5 & 31.3 \\
\hline & & Disagree & 0 & 0.0 & 1 & 1.2 & 1 & 1.6 & 0 & 0.0 \\
\hline & $\begin{array}{l}\text { Favourable context: educational } \\
\text { institutions }\end{array}$ & Agree & 40 & 57.1 & 38 & 45.8 & 15 & 26.3 & 6 & 37.6 \\
\hline & & Neither agree nor disagree & 8 & 11.4 & 29 & 34.9 & 13 & 21.3 & 5 & 31.3 \\
\hline & & Disagree & 0 & 0.0 & 4 & 4.8 & 2 & 3.3 & 0 & 0.0 \\
\hline \multirow[t]{26}{*}{ Control } & Country & Argentina & 0 & 0.0 & 0 & 0.0 & 0 & 0.0 & 0 & 0.0 \\
\hline & & Australia & 5 & 7.1 & 6 & 7.2 & 4 & 6.6 & 2 & 11.8 \\
\hline & & Austria & 0 & 0.0 & 0 & 0.0 & 1 & 1.6 & 0 & 0.0 \\
\hline & & Belgium & 0 & 0.0 & 2 & 2.4 & 3 & 4.9 & 0 & 0.0 \\
\hline & & Brazil & 2 & 2.9 & 0 & 0.0 & 0 & 0.0 & 2 & 11.8 \\
\hline & & Canada & 6 & 8.6 & 3 & 3.6 & 6 & 9.8 & 1 & 5.9 \\
\hline & & Chile & 1 & 1.4 & 0 & 0.0 & 0 & 0.0 & 0 & 0.0 \\
\hline & & Denmark & 0 & 0.0 & 1 & 1.2 & 1 & 1.6 & 0 & 0.0 \\
\hline & & France & 3 & 4.3 & 3 & 3.6 & 4 & 6.6 & 1 & 5.9 \\
\hline & & Germany & 2 & 2.9 & 3 & 3.6 & 6 & 9.8 & 0 & 0.0 \\
\hline & & Ireland & 1 & 1.4 & 1 & 1.2 & 0 & 0.0 & 0 & 0.0 \\
\hline & & Italy & 1 & 1.4 & 3 & 3.6 & 4 & 6.6 & 0 & 0.0 \\
\hline & & Latvia & 0 & 0.0 & 0 & 0.0 & 1 & 1.6 & 0 & 0.0 \\
\hline & & Netherlands & 0 & 0.0 & 2 & 2.4 & 0 & 0.0 & 0 & 0.0 \\
\hline & & New Zealand & 1 & 1.4 & 1 & 1.2 & 0 & 0.0 & 2 & 11.8 \\
\hline & & Norway & 2 & 2.9 & 0 & 0.0 & 0 & 0.0 & 0 & 0.0 \\
\hline & & South Africa & 0 & 0.0 & 0 & 0.0 & 1 & 1.6 & 0 & 0.0 \\
\hline & & Spain & 1 & 1.4 & 1 & 1.2 & 2 & 3.3 & 0 & 0.0 \\
\hline & & Sweden & 0 & 0.0 & 1 & 1.2 & 2 & 3.3 & 0 & 0.0 \\
\hline & & Switzerland & 0 & 0.0 & 0 & 0.0 & 2 & 3.3 & 0 & 0.0 \\
\hline & & United Kingdom & 30 & 42.9 & 43 & 51.8 & 10 & 16.4 & 4 & 23.5 \\
\hline & & United States of America & 12 & 17.1 & 13 & 15.7 & 15 & 24.6 & 5 & 29.4 \\
\hline & Duration (years) & Mean & 4.16 & - & 3.98 & - & 2.69 & - & 3.63 & - \\
\hline & & Std dev & 1.99 & - & 1.45 & - & 0.99 & - & 1.09 & - \\
\hline & Steps & Mean & 9.87 & - & 8.51 & - & 6.77 & - & 6.00 & - \\
\hline & & Std dev & 1.61 & - & 2.27 & - & 2.00 & - & 2.92 & - \\
\hline
\end{tabular}




\section{Discussion}

The analysis of the replication of transition initiatives sheds light on the conditions of success and failure of grassroots innovations in different local contexts. In this section, we summarise this study's main results and discuss its relevance for research on the conditions for grassroots innovation success as a form of response to environmental change in consideration of three under-explored areas of the literature.

\subsection{Success and failure of grassroots innovations}

The majority of the transition initiatives considered themselves at least fairly successful (Table 2). The literature on grassroots innovations suggests that there are many ways of defining the success or failure of grassroots innovations (e.g. Howaldt and Schwarz, 2010; Kirwan et al., 2013; Ornetzelder and Rohracher, 2013), which is related to the different motivations of grassroots innovations (Seyfang and Longhurst, 2013). Thus, it is generally agreed that the success of grassroots innovations can be identified (i) through their social links to members of local communities, building capacity and empowering social actors (e.g. Middlemiss and Parrish, 2010), as well as (ii) through their external impact or contribution to improved environmental performance (Barthelmie et al., 2008), or different trajectories of systemic socio-technical innovation (e.g. Geels and Schot, 2007).

Our results confirm the coexistence of these two broad sets of criteria. The respondents defined the success of their transition initiative by referring both to the social function (exemplified by the values of conviviality, 'fun', or sense of community) and external impact, with a critical mass of members being a characteristic that cross-cuts the two dimensions (Table A.4 in the Electronic Supplementary Materials). Democratic organisational principles also were considered to be key characteristics of successful transition initiatives, which confirms what has been suggested by other studies (e.g. Seyfang and Smith, 2007; Kirwan et al., 2013; Ornetzelder and Rohracher, 2013). These results were consistent with the objective measure of success, whereby subjectively successful transition initiatives also tended to be more mature (i.e. have lasted longer), to involve more members, and to undertake more 'steps to transition'. Though the latter only should be taken as a proxy for the level of transition initiative development, considering that these steps represent general guidelines and principles (Brangwyn and Hopkins, 2008) that are locally adapted (Pickerill and Maxey, 2009), they should be taken as a means, rather than a goal, of transition. In addition, some of the steps to transition have a cyclical nature rather than being one-off targets. Nevertheless, together with the other objective indicators, the steps to transition may provide an indication of the underpinning dynamics of capacity building, social links to local communities, and narrative and identity development that have been suggested to be key factors in the success of grassroots innovations (Middlemiss and Parrish, 2010; Connors and McDonald, 2011; Feola, 2012).

The results also suggest that less successful transition initiatives might underestimate contextual factors and material resources, which this study shows are significant in the success of transition initiatives (Tables 7 and 8). Transition initiatives might have a low awareness of contextual conditions of success or failure, and instead, tend to consider the factors they can control as the most important, among which are the recruitment, self-organisation and motivation of members. The little importance given to material resources might be explained by the high reliance of most of transition initiatives on the contribution of volunteers (Table 4), which however is often a barrier to success (Smith, 2011). Such a mismatch in the consideration given to conditions of success or failure might be due to a tendency to look inwardly. This may be a result of the necessity to build up innovative niches, especially in the early stages of transition initiative development where the majority of respondents identify their initiatives. Thus, a corollary of this finding would suggest the criteria used for assessing success, both subjectively and objectively, might change during the development of a grassroots innovation, and consequently also the evaluation of those criteria. This is a hypothesis worth testing in future research. 


\subsection{Factors of success and failure of grassroots innovations}

Our results confirmed many of the hypotheses, albeit mostly drawn from single in-depth case studies, present in the literature that guided this study (Table 1). We identified types of transition initiatives that were based on typical configurations of conditions for success and failure into four clusters (Table 9), which occur in different contexts. These ideal types do not represent formulae for more, or less success. Rather, the complex nature of socio-technical systems and the high diversity of grassroots innovations make success or failure unpredictable (Bergman et al., 2010). We did not unravel the varied interrelationships among factors of grassroots innovations' success or failure, which generate these patterns of local configurations, although we do argue that the identified ideal types represent a useful step forward in the understanding of local settings and structural conditions (Ornetzelder and Rohracher, 2013) that may facilitate or hinder the diffusion of grassroots innovations.

Following Brown et al. (2012), we discuss here these ideal-types in relation to the three underexplored areas of interrelated literature referred to earlier in this paper: i) the combination of different forms of transition - lifecourse, environmental and political-economic - which assumes a consolidation and standardisation of learning processes that may drive the growth and development or replication of grassroots innovations (Seyfang and Longhurst, 2013); ii) the compulsion to act through a form of affective governance that, in seeking to embed an alternative to conventional processes, results in a trade-off between successful diffusion and innovation control (Geels and Schot, 2007; Ornetzelder and Rohracher, 2013); and lastly iii) the emplacement or spatial contexts of sociotechnical transitions (Coenen et al., 2012; Devine-Wright, 2013).

First, our results do suggest that transition initiatives' growth and development is linked to the combination of local-global (trans-local) learning processes (e.g. externally resourced transition training/permaculture training). This would confirm that transition initiatives may be interdependent with global action networks whilst retaining a strong promotion of the 'local' (Mayer and Knox, 2010; North, 2010; Wilson, 2012). Also, cooperation with other transition initiatives in the Transition Movement and other actors such as local authorities and businesses is essential to transition initiative success. Yet despite most transition initiatives acknowledging a favourable context for such cooperation, least successful transition initiatives have not engaged with other actors.

In addition, several transition guidelines, promoted by the Transition Network at the transition initiative level, mark the difference between clusters of highly or less successful initiatives (Table 9). In particular, the Transition Network recognition of transition initiatives and the organisation into subgroups are related to transition initiative success. They interact with other important factors such as the level of human resources (i.e. size of the steering group for those transition initiatives that have one), time and money (external funds), which confirms earlier evidence presented by Middlemiss and Parrish (2010).

Our results also suggest that there may be an incubation period for success of approximately four years (Table 9). Moreover, a longer period before becoming 'official' is associated with high levels of success (Table 9), which reinforces the hypothesis of an incubation period during which the transition initiative is consolidated and builds the basis for future success. However, future longitudinal studies will be required to test this hypothesis. These results suggest that there may be a point when transition-related learning processes, evident in transition initiative growth and development may peak or plateau due to a limited supply of volunteer support. Alternatively, these results may be an indicator of 'creative destruction' or learning processes where old knowledge and ways of learning are discarded in favour of new approaches or recombined with new ideas or processes. Therefore, grassroots innovation success may be consistent with learning cycles of intermittent periods of coherence as well as fragmentation and variety, considering transition initiative success is conditional upon resources and membership activity, whereby peer-to-peer knowledge dissemination complements a process of dis/aggregation, re/consolidation and de/standardisation (Seyfang and Longhurst, 2013). A similar cyclical development has been identified in social innovation by Westley 
et al. (2006) and Biggs et al. (2010). Overall, this would suggest that transition initiative success remains largely determined by situated processes despite its interdependence with global action networks.

Second, we find that the context of transition initiative success or failure can be linked to a compulsion to act. Despite the lesser role of steering groups, as well as the legal status or official recognition of transition initiative success, the formal structure of the Transition Network seems to play a significant role in at least two ways. Firstly, it generates the grand narrative of transition (Feola, 2012) and delivers the training that equips local groups with the skills needed to cope with and manage the transition process. The training is often based on mature successful experiences and therefore it also has a function of knowledge sharing that supports learning and niche building (Seyfang and Longhurst, 2013). Secondly, the Transition Network provides general principles and organisational guidelines such as the 12 'steps to transition' (Brangwyn and Hopkins, 2008; Connors and McDonald, 2010), several of which, including those related to internal organisation and collaboration with other actors, we found to be associated with a high degree of transition initiative success (Tables 7, 8 and 9). Thus, in contrast to what Devine-Wright and Wiersma (2013) suggest, the Transition Movement seems capable of generalising organisational principles derived from 'unique' local experiences that overall seem to be effective in other unique local contexts, and to 'hold the future [orientation for the movement] together' (Brown et al., 2012, p. 1616).

Lastly, this brings us to our final consideration of the emplacement of transition initiatives. Despite the frequent and active use of online social networking made within and between transition initiatives in the Transition Movement, this study also suggests that the geographical location of the transition initiative matters. Transition initiatives located in areas characterised by a higher density of other transition initiatives and where there are active regional or national Transition Network hubs, have a greater chance of interacting with other transition initiatives, as was the case for transition initiatives in the United Kingdom (Truffer and Coenen, 2012). This seems to confirm the positive role played by networking among grassroots innovations for their success (Seyfang and Longhurst, 2013), and suggests the importance of 'offline' contact despite the growing use of 'online' tools for communication, information sharing and recruitment. These results are also consistent with those suggested by Mulugetta et al. (2010), according to whom 'it is much easier for neighbouring communities to share experiences since they are likely to face similar problems and can negotiate a shared vision about addressing climate mitigation and adaptation requirements' (Mulugetta et al., 2010 , p. 7543). On the contrary, geographically isolated transition initiatives, even if virtually connected (online) in the Transition Movement, seem more at risk of being discontinued or to struggle to achieve momentum and thrive.

We also find that the least successful or non-active transition initiatives are located predominantly, although not exclusively, in urban areas (Table 9). Long-established research (e.g. discussed by Lewicka, 2011) has explored the links between place attachment and pro-environmental behaviour, and recent studies have begun to explore global level, as well as local level attachments (DevineWright, 2013). Our results would suggest that local attachments among urban transition initiatives are weak and not compensated by global attachments to the wider Transition Network. Whether this is due to some combination of dynamic urban characteristics that do not reinforce local attachments to place, and the 'eco-localisation' response to climate change by the Transition Movement (North, 2010; Mason and Whitehead, 2012) is unclear. On a related note, our results also confirm that the level of diversity representation and inclusivity is lowest among urban transition initiatives. This may suggest that other complementary values, motivations and routes to low-carbon lifestyles need to be explored (Antonsich, 2010). The importance of diversity representation has been pointed out by previous studies, albeit without reference to a specific type of transition initiative.

\subsection{Limitations and directions for future research}

The literature has shown that the development of grassroots innovations is not linear, but is likely to be proceeded by a sequence of positive and more critical periods that might involve several failed attempts before success occurs (Bergman et al., 2010; Biggs et al., 2010). As suggested by this study, 
it seems that grassroots innovations go through an initial period of incubation during which they take momentum (see also Ornetzelder and Rohracher, 2013 and more generally the literature on transition, e.g. Smith et al., 2005). As mentioned above, in the course of such development not only the value of the indicators of success and failure may change significantly, but there might be the need for different indicators, both subjective and objective. Due to its cross-sectional nature, this study could not capture such dynamics. For the same reason, it was not possible in this study to determine what conditions play a significant role at what stage of the transition initiative development. It can be hypothesised that some configurations of factors might exert influence at particular development stages of grassroots innovations. For example, skills acquisition, e.g. through the transition training, might be particularly important in the early stages of grassroots innovation development. These aspects have potentially important policy and practical implications and therefore represent an interesting avenue for future research that should be addressed with a longitudinal research design, including case studies with focused surveys or long-term 'panel' studies.

It is also widely acknowledged that the success or failure of grassroots innovations, especially if measured in terms of external impact on a socio-technical regime, depends on the simultaneous pressure of the grassroots innovation 'niche' and 'landscape' trends, which create windows of opportunity for change (e.g. Smith et al., 2005). The failure of grassroots innovations is often ascribed to the co-option of its innovative values, practices or technologies by the mainstream (e.g. Smith, 2005; Bergman et al., 2010). While some global framings of risk such as climate change and peak oil exist, and are indeed utilised by the Transition Movement to build its grand narrative (Brown et al., 2012; Feola, 2012), the success of individual transition initiatives is likely to depend also on regional or local framings that we were unable to investigate in this study. Nevertheless, more work is required on grassroots innovation success and failure, and its roots in pre-existing networks, institutional 'lockin', as well as the local and global linkages to the place, sites and situations or events through which the practice of climate change adaptation and mitigation is performed, contested and validated (Nunes, 2013). A more systematic comparative investigation of such niche-landscape dynamics in different spatial contexts could shed further light on the configurations of conditions that favour or hinder the successful replication and scale-up of grassroots innovations.

\section{Conclusions}

In this first international survey of transition initiatives of the Transition Movement, we have identified definitions of success factors in the literature on transition and have linked varying configurations of these factors to different degrees of success and failure. This study has shed light on the diffusion (i.e. replication) of grassroots innovations in different contexts, complementing in-depth, and mostly qualitative, case studies of individual grassroots innovations. It also offers new insights into open theoretical questions that inform future research on transition towards sustainable and resilient communities, as well as the on-going practice and future pursuits of transition initiatives.

We conclude that the success of transition initiatives is defined along the lines of social connectivity and empowerment, and external impact or contribution to environmental performance. In this paper we have correlated the success of transition initiatives to objective measures of activity and participation (i.e. members, duration, activities undertaken - steps to transition), though there remains scope for refining these objective measures, e.g. a function of different development stages of transition initiatives. We also conclude that transition initiative members tend to focus on internal, and overlook external factors of transition initiative success, which may be related to a lack of awareness of their environment, of skills to engage with it, or the need to focus on the most controllable factors in early stages of development. Nevertheless our results do suggest that, whilst there is no formula for more, or less success, transition initiatives can be arranged into four typical configurations or clusters of variable success and failure. 
Finally, in our discussion of these survey findings we shed light on some key open issues in transition theory with regard to the combination of different forms of transition, the compulsion to act, as maintained by the reiterated narratives of risk-laden futures, and the emplacement or 'place attachment' of transition initiatives. We identify two interrelated observations. First, our research suggests that transition initiatives remain largely determined by situated processes despite their interdependence with a global action network like the Transition Movement. In other words local and global 'place attachments' encourage pro-environmental behaviour, but local contextual factors largely determine the success and failure of associated community initiatives. Second, in contrast to what Devine-Wright and Wiersma (2013) suggest, whilst the Transition Network seems capable of generalising organisational principles of good practice from 'unique' local experiences that may have global application, our results suggest that local place attachments among urban transition initiatives are weak and not compensated by their interdependent links to global action networks. Both observations arguably have significant implications for future research on the growing interest in lowcarbon urban initiatives and merit future investigation through longitudinal studies.

\section{Acknowledgments}

The authors are grateful to all members of the transition initiatives who took their time to participate in this study, and to those who did not but who sent constructive critiques and comments that helped the authors improve the research. Celeste Salter, Michelle Bastian, Marco Mauri, Isabela Maria Gomez de Menezes, Holly Salvidge, Jesus Cordero-Salvado, Janine Baudach, Sophie Raynaud and Rogerio Henrique de Abreu provided invaluable help at different stages of the survey design, translation and dissemination. The authors also thank Amy Burnett, Peter McManners and Gill Seyfang for their comments on an earlier version of this manuscript, and Joan Allibone for proof reading. The project was co-funded by the School of Human and Environmental Sciences and the School of Real Estate and Planning at the University of Reading.

\section{References}

\section{Aiken, G., 2012. Community transitions to low carbon futures in the Transition Towns Network (TTN). Geography Compass 6, 89-99.}

Antonsich, M., 2010. Meanings of place and aspects of the self: an interdisciplinary and empirical account. GeoJournal 75 (1), 119-132.

Barthelmie, R.J., Morris, S.D., Schechter, P., 2008. Carbon neutral Biggar: calculating the community carbon footprint and renewable energy options for footprint reduction. Sustainability Science 3, 267282.

Bergman, N., Markusson, N., Connor, P., Middlemiss, L., Ricci, M., 2010. Bottom-up, social innovation for addressing climate change. In: Energy transitions in an interdependent world: what and where are the future social science research agendas, Sussex, 25-26 February 2010.

Biggs, R., Westley, F.R., Carpenter, S.R., 2010. Navigating the back loop: fostering social innovation and transformation in ecosystem management. Ecology and Society 15, 9.

Brangwyn, B., Hopkins, R., 2008. Transition Initiatives Primer. Available at http://www.transitionnetwork.org/sites/www.transitionnetwork.org/files/TransitionInitiativesPrimer(3 ..pdf (accessed 30 July 2013).

Brown, G., Kraftl, P., Pickerill, J., Upton, C., 2012. Holding the future together: towards a theorisation of the spaces and times of transition. Environment and Planning A 44 (7), 1607-1623. 
Feola, G., Nunes, J.R. 2014. Success and failure of Grassroots Innovations for addressing climate change: the case of the Transition Movement. Global Environmental Change 24, 232-250.

Bulkeley, H., 2005. Reconfiguring environmental governance: towards a politics of scales and networks. Political Geography 24 (8), 875-902.

Bulkeley, H., Kern, K., 2006. Local government and the governing of climate change in Germany and the UK. Urban Studies 43 (12), 2237-2259.

Burch, S., 2010. Transforming barriers into enablers of action on climate change: insights from three municipal case studies in British Columbia, Canada. Global Environmental Change 20, 287-297.

Castán Broto, V., Bulkeley, H., 2013. A survey of urban climate change experiments in 100 cities. Global Environmental Change 23, 92-102.

Chiu, T., Fang, D., Chen, J., Wang, Y., Jeris, C., 2001. A Robust and Scalable Clustering Algorithm for Mixed Type Attributes in Large Database Environment. Proceedings of the Seventh ACM SIGKDD International Conference on Knowledge Discovery and Data Mining, 263.

Church, C., Elster, J., 2002. Thinking Locally, Acting Nationally: Lessons for National Policy from Work on Local Sustainability. Joseph Rowntree Foundation, York.

Coenen, L., Benneworth, P., Truffer, B., 2012. Toward a spatial perspective on sustainability transitions. Research Policy 41, 968-979.

Connors, P., McDonald, P. 2011. Transitioning communities: community, participation and the Transition Town movement. Community Development Journal 46 (4), 558-572.

Devine-Wright, P., 2013. Think global, act local? The relevance of place attachments and place identities in a climate changed world. Global Environmental Change 23, 61-69.

Devine-Wright, P., Wiersma, B., 2013. Opening up the "local" to analysis: exploring the spatiality of UK urban decentralised energy initiatives. Local Environment, doi:10.1080/ 13549839.2012.754742.

Douglas M., Wildawsky A., 1983. Risk and Culture: An Essay on the Selection of Technological and Environmental Dangers. University of California Press, Los Angeles.

Feitelson, E., 1991. Sharing the globe: the role of attachment to place. Global Environmental Change 1 (5), 396-406.

Feola, G. 2012. Voluntary simplicity and Transition Network: a comparison of narratives, practices and strategies. Paper presented at the $18^{\text {th }}$ Annual International Sustainable Development Research Conference, 24-26 June 2012, University of Hull, United Kingdom.

Geels, F., Schot, J., 2007. Typology of sociotechnical transition pathways. Research Policy 36, 399_ 417.

Glasbergen, P., 2010. Global action networks: agents for collective action. Global Environmental Change 20,130-141.

Grin, J., Rotmans, J., Schot, J.W., 2010. Transitions to Sustainable Development: New Directions in the Study of Long Term Transformative Change. Routledge, Abingdon.

Hargreaves, T., Longhurst, N., Seyfang, G., 2013. Up, down, round and round: connecting regimes and practices in innovation for sustainability. Environment and Planning A 45 (2), 402-420.

Haxeltine, A., Seyfang, G. 2009. Transitions for the People: theory and practice of 'Transition' and 'Resilience' in the UK's Transition movement. Tyndall Centre for Climate Change Research Working Paper 134. 
Hodson, M., Marvin, S., 2010. Can cities shape socio-technical transitions and how would we know if they were? Research Policy 39 (4), 477-485.

Hoffman, S.M., High-Pippert, A., 2010. From private lives to collective action: recruitment and participation incentives for a community energy program. Energy Policy 38, 7567-7574.

Holloway, J., Sergi, V., 2010. Crack Capitalism. Pluto Press, London.

Holmgren, D., 2004. Permaculture: Principles and pathways beyond sustainability. Holmgren Design Press.

Hopkins, R., 2008. The Transition Handbook. Green Books, Totnes.

Hopkins, R., 2011. The Transition Companion. Green Books, Totnes.

Howaldt, J., Schwarz, M., 2010. Social innovation: concepts, research fields and international trends. K. Henning, F. Hees (Eds.). IMA/ZLW.

IPCC, 2007. Climate change 2007: synthesis report. In: Core Writing Team, Pachauri, R.K., Reisinger, A. (Eds.), Contribution of Working Groups I, II and III to the Fourth Assessment Report of the Intergovernmental Panel on Climate Change, IPCC, Geneva.

Kirwan, J., Ilbery, B., Maye, D., Carey, J., 2013. Grassroots social innovations and food localisation: an investigation of the local food programme in England. Global Environmental Change, http://dx.doi.org/10.1016/j.gloenvcha.2012.12.004.

Leach, M., Rockström, J., Raskin, P., Scoones, I., Stirling, A.C., Smith, A., Thompson, J., Millstone, E., Ely, A., Arond, E., Folke, C., Olsson, P., 2012. Transforming innovation for sustainability. Ecology and Society 17 (2), 11.

Lewicka, M., 2011. Place attachment: how far have we come in the last 40 years? Journal of Environmental Psychology 31 (3), 207-230.

Mason, K., Whitehead, M., 2012. Transition urbanism and the contested politics of ethical place making. Antipode 44 (2), 493-516.

Mayer, H., Knox, P., 2010. Small-town sustainability: prospects in the second modernity. European Planning Studies 18, 1545-1565.

Merritt, A., Stubbs, T., 2012. Incentives to promote green citizenship in UK transition towns. Development 55 (1), 96-103.

Middlemiss, L., Parrish, B.D., 2010. Building capacity for low-carbon communities: the role of grassroots initiatives. Energy Policy 38, 7559-7566.

Moloney, S., Horne, R.E., Fien, J., 2010. Transitioning to low carbon communities-from behaviour change to systemic change: lessons from Australia. Energy Policy 38, 7614-7623.

Moulaert, F., Martinelli, F., Swyngedouw, E., Gonzalez, S., 2005. Towards alternative model(s) of local innovation. Urban Studies 42, 1969-1990.

Mulgan, G., 2006. The process of social innovation. Innovations: Technology, Governance, Globalization, 1 (2), 145-162.

Mulugetta, Y., Jackson, T., Van der Horst, D., 2010. Carbon reduction at community scale. Energy Policy $38,7541-7545$. 
Feola, G., Nunes, J.R. 2014. Success and failure of Grassroots Innovations for addressing climate change: the case of the Transition Movement. Global Environmental Change 24, 232-250.

Neumeier, S., 2012. Why do Social Innovations in Rural Development Matter and Should They be Considered More Seriously in Rural Development Research? - Proposal for a Stronger Focus on Social Innovations in Rural Development Research. Sociologia Ruralis 52, 48-69.

North, P., 2010. Eco-localisation as a progressive response to peak oil and climate change - a sympathetic critique. Geoforum 41 (4), 585-594.

Norusis, M., 2012. IBM SPSS Statistics 19 Statistical Procedures Companion. Pearson.

Nunes, R.J., 2013. The place of community-led enterprise in the everyday politics of Transition practice. In: AAG Association of American Geographer Annual Meeting, 9-13 April, Los Angeles.

O'Brien, K., 2012. Global environmental change II: from adaptation to deliberate transformation. Progress in Human Geography 36, 667-676.

Ornetzelder, M., Rohracher, H. 2013. Of solar collectors, wind power, and car sharing: comparing and understanding successful cases of grassroots innovations. Global Environmental Change, doi:10.1016/j.gloenvcha.2012.12.007.

Peters, M., Fudge S., Jackson T., 2012. Low Carbon Communities: Imaginative Approaches to Combating Climate Change Locally. Edward Elgar, London.

Pickerill, J., Maxey, L., 2009. Geographies of sustainability: low impact developments and radical spaces of innovation. Geography Compass 3, 1515-1539.

Quilley, S., 2012. Resilience Through Relocalization: Ecocultures of Transition? Ecocultures Working Paper: 2012-1, Univeristy of Essex.

Scannell, L., Gifford R., 2010. Defining place attachment: a tripartite organizing framework. Journal of Environmental Psychology 30 (1), 1-10.

Schot, J., Geels, F.W., 2008, Strategic niche management and sustainable innovation journeys: theory, findings, research agenda, and policy. Technology Analysis \& Strategic Management 20, 537-554

Scott-Cato, M., Hillier, J., 2010. How could we study climate-related social innovation? Applying Deleuzean philosophy to Transition Towns. Environmental Politics 19, 869-887.

Seyfang, G., Longhurst, N., 2013. Desperately seeking niches: grassroots innovations and niche development in the community currency field. Global Environmental Change, doi:10.1016/j.gloenvcha.2013.02.007.

Seyfang, G., Haxeltine A., 2012. Growing grassroots innovations: exploring the role of communitybased initiatives in governing sustainable energy transitions. Environment and Planning C 30, 381400 .

Seyfang, G., 2011. The New Economics of Sustainable Consumption: Seeds of Change. Palgrave Macmillan, Basingstoke.

Seyfang, G., Smith, A., 2007. Grassroots innovations for sustainable development: towards a new research and policy agenda. Environmental Politics 16, 584-603.

Smith, A., 2011. The transition town network: a review of current evolutions and renaissance. Social Movement Studies 10, 99-105.

Smith, A., 2005. Green niches in sustainable development: the case of organic food in the United Kingdom. Environment and Planning C 24, 439-458. 
Smith, A., Stirling, A., Berkhout, F., 2005. The governance of sustainable socio-technical transitions. Research Policy 34, 1491-1510.

Smith, A., Raven, R., 2012. What is protective space? Reconsidering niches in transitions to sustainability. Research Policy 41, 1025-1036.

Späth, P., Rohracher, H., 2012. Local demonstrations for global transitions-dynamics across governance levels fostering socio-technical regime change towards sustainability. European Planning Studies 20, 461-479.

Transition Network, 2012. Available at http://www.transitionnetwork.org (accessed 30 July 2013).

TRAPESE, 2008. The Rocky Road to Transition: The Transition Towns Movement and What It Means for Social Change. Trapese Collective.

Truffer, B., Coenen, L., 2012. Environmental innovation and sustainability transitions in regional studies. Regional Studies 46 (1), 1-21.

Veenhoven, R., 2002. Why social policy needs subjective indicators. Social Indicators Research 58, $33-46$.

Walker, G., 2011. The role for "community" in carbon governance. Wiley Interdisciplinary Reviews: Climate Change 2, 777-782.

Wells, P., 2011. The transition initiative as a grass-roots environmental movement: history, present realities and future predictions. Interdisciplinary Environmental Review 12, 372-386.

Westley, F.R., Zimmerman, B., Patton, M.Q., 2006. Getting to maybe: how the world is changed. Vintage Canada, Toronto.

Wilson, G.A., 2012. Community resilience, globalization, and transitional pathways of decisionmaking. Geoforum 43, 1218-1231.

Young, O.R., 2011. Effectiveness of international environmental regimes: existing knowledge, cutting-edge themes, and research strategies. Proceedings of the National Academy of Sciences 108, 19853-19860. 
Feola, G., Nunes, J.R. 2014. Success and failure of Grassroots Innovations for addressing climate change: the case of the Transition Movement. Global Environmental Change 24, 232-250.

\section{Appendix}


Feola, G., Nunes, J.R. 2014. Success and failure of Grassroots Innovations for addressing climate change: the case of the Transition Movement. Global Environmental Change 24, 232-250.

Table A.1. Independent variables. 
Feola, G., Nunes, J.R. 2014. Success and failure of Grassroots Innovations for addressing climate change: the case of the Transition Movement. Global Environmental Change 24, 232-250.

\begin{tabular}{|c|c|c|}
\hline Group & List of variables & Description \\
\hline \multirow{8}{*}{$\begin{array}{l}\text { Transition } \\
\text { initiative } \\
\text { characteristics }\end{array}$} & Type of transition initiative & Urban/city; Village; Rural; Forest; Island; Town \\
\hline & National hub & The Transition initiative is a national Transition Network hub \\
\hline & Regional hub & The Transition initiative is a regional Transition Network hub \\
\hline & Legal form & The Transition initiative is constituted in a legal form \\
\hline & Themes addressed & $\begin{array}{l}\text { Theme addressed through community initiatives: Arts and Crafts; Business and Economics; Diversity and Social Justice; Education; Effective groups; } \\
\text { Energy; Food; Health; Housing; Inner transition; Locla government; Transport; Other theme; Multiple themes }\end{array}$ \\
\hline & First theme addressed & $\begin{array}{l}\text { First theme addressed through community initiatives: Arts and Crafts; Business and Economics; Diversity and Social Justice; Education; Effective groups; } \\
\text { Energy; Food; Health; Housing; Inner transition; Locla government; Transport; Other theme; Multiple themes }\end{array}$ \\
\hline & Official recognition & The Transition initiative has achieved official recognition of the Transition Movement \\
\hline & Years to become official & The number of years from foundation to official recognition of the Transition Movement \\
\hline \multirow[t]{10}{*}{ Members } & Age of members & $<30 ; 31<>49 ; 50<>65 ;>65$ \\
\hline & Transition training & Number of members of the steering group that have had official (i.e. delivered by the TTN) transition training \\
\hline & Transition training ratio & Ratio of members of the steering group with official transition training on the total of steering group members \\
\hline & Permaculture training & Number of members of the steering group that have had training in permaculture or have knowledge of it \\
\hline & Permaculture training ratio & Ratio of members of the steering group with training in permaculture or have knowledge of it on the total of steering group members \\
\hline & Education of steering group members & Level of education of the steering group members: no qualification; below university degree level; university degree level or above \\
\hline & Occupation & Occupation of the majority of Transition initiative members: Unemployed, Student; In emplyment; Pensioner \\
\hline & Diversity & $\begin{array}{l}\text { How well the composition of the Transition initiative members mirrors the diversity in the community: Very good; Fairly good, Not very good, Not good at } \\
\text { all }\end{array}$ \\
\hline & Founders number & Number of original founders of the transition initiative \\
\hline & Preexistence group & The founders of the transition initiative belonged to another grassroots group before founding the transition initiative \\
\hline \multirow[t]{30}{*}{ Organisation } & Steering group & The transition initiative has a steering/coordination group \\
\hline & Number of steering group members & Number of steering group members \\
\hline & Subgroups & The transition initiative is organised in subgroups \\
\hline & Paid staff & $\begin{array}{l}\text { Poportion of members of the steering group that are paid staff: All members of the steering group are paid staff (100\%); Most of the members of the } \\
\text { steering group are paid staff (about 75\%); There are an equal number of paid staff and volunteers in the steering group; Some members of the steering } \\
\text { group are paid staff (about 25\%); None of the members of the steering group are paid staff (0\%) }\end{array}$ \\
\hline & Recruitpers & The transition initiative recruits new members through personal contacts \\
\hline & Recruitwork & The transition initiative recruits new members through workshops \\
\hline & Recruitevent & The transition initiative recruits new members through communication events \\
\hline & Recruitweb & The transition initiative recruits new members through website \\
\hline & Recruite & The transition initiative recruits new members through electronic materials (e.g. newsletter) \\
\hline & Recruitprint & The transition initiative recruits new members through printed materials \\
\hline & Recruitno & The transition initiative does not actively recruit new members \\
\hline & Conflict resolution & The transition initiative has mechanism for effective conflict resolution \\
\hline & Political orientation & The transition initiative has a declared political orientation \\
\hline & Intcompers & The transition initiative communicates internally by means of personal contacts \\
\hline & Intcomwork & The transition initiative communicates internally by means of workshops \\
\hline & Intcomevent & The transition initiative communicates internally by means of communication events \\
\hline & Intcomweb & The transition initiative communicates internally by means of website \\
\hline & Intcome & The transition initiative communicates internally by means of electronic materials (e.g. mailing list) \\
\hline & Intcomprint & The transition initiative communicates internally by means of printed materials \\
\hline & Intcomno & The transition initiative does no communicate internally \\
\hline & Intcomother & The transition initiative communicates internally by other means \\
\hline & Extcompers & The transition initiative communicates externally by means of personal contacts \\
\hline & Extcomwork & The transition initiative communicates externally by means of workshops \\
\hline & Extcomevent & The transition initiative communicates externally by means of communication events \\
\hline & Extcomweb & The transition initiative communicates externally by means of website \\
\hline & Extcome & The transition initiative communicates externally by means of electronic materials (e.g. mailing list) \\
\hline & Extcomprint & The transition initiative communicates externally by means of printed materials \\
\hline & Extcomno & The transition initiative does no communicate externally \\
\hline & Extcomother & The transition initiative communicates externally by other means \\
\hline & Web & The transition initiative has an online presence (website, blog, social network page) \\
\hline \multirow[t]{7}{*}{ Resources } & Proportion of external funding & $\begin{array}{l}\text { Proportion of funds that is external: All funds were external (100\%); Most of the funds were external (about 75\%); There were equal proportions of } \\
\text { external and internal funds; Little funds were external (about 25\%); No funds were external (0\%) }\end{array}$ \\
\hline & Time dedicated by steering group & Hours per week dedicated to the transition initiative by the steering group members \\
\hline & Resroom & The Transition initiative disposes of a meeting room \\
\hline & Resoffice & The Transition initiative disposes of an office \\
\hline & Respc & The Transition initiative disposes of a computer \\
\hline & Resprint & The Transition initiative disposes of a printer \\
\hline & Resvideo & The Transition initiative disposes of equipment for video reproduction \\
\hline \multirow[t]{18}{*}{ Context } & Participatory democracy & There are forms of participatory democracy in the locality \\
\hline & Cooperation with local authorities & The transition initiative cooperates with local authorities: Yes currently; Yes in the past; No \\
\hline & Cooperation with mass media & The transition initiative cooperates with local mass media: Yes currently; Yes in the past; No \\
\hline & Cooperation with local business & The transition initiative cooperates with local businesses: Yes currently; Yes in the past; No \\
\hline & Cooperation with social enterprises & The transition initiative cooperates with social enterprises: Yes currently; Yes in the past; No \\
\hline & Cooperation with NGOs & The transition initiative cooperates with other NGOs: Yes currently; Yes in the past; No \\
\hline & $\begin{array}{l}\text { Cooperation with other Transition } \\
\text { initiatives }\end{array}$ & The transition initiative cooperates with other transition initiatives: Yes currently; Yes in the past; № \\
\hline & $\begin{array}{l}\text { Cooperation with regional/national } \\
\text { Transition Network hub }\end{array}$ & The transition initiative cooperates with regional/national Transition Network hubs: Yes currently; Yes in the past; No \\
\hline & $\begin{array}{l}\text { Cooperation with educational } \\
\text { institutions }\end{array}$ & The transition initiative cooperates with research/educational institutions: Yes currently; Yes in the past; No \\
\hline & Favourable context: local authorities & The transition initiative thinks it is well perceived by local authorities: Agree strongly; Agree, Neither agree nor disagree; Disagree; Disagree strongly \\
\hline & Favourable context: mass media & The transition initiative thinks it is well perceived by local mass media: Agree strongly; Agree, Neither agree nor disagree; Disagree; Disagree strongly \\
\hline & Favourable context: local business & The transition initiative thinks it is well perceived by local businesses: Agree strongly; Agree, Neither agree nor disagree; Disagree; Disagree strongly \\
\hline & Favourable context: social enterprises & The transition initiative thinks it is well perceived by social enterprises: Agree strongly; Agree, Neither agree nor disagree; Disagree; Disagree strongly \\
\hline & Favourable context: NGOs & The transition initiative thinks it is well perceived by other NGOs: Agree strongly; Agree, Neither agree nor disagree; Disagree; Disagree strongly \\
\hline & Favourable context: other TIs & $\begin{array}{l}\text { The transition initiative thinks it is well perceived by other transition initiatives: Agree strongly; Agree, Neither agree nor disagree; Disagree; Disagree } \\
\text { strongly }\end{array}$ \\
\hline & Favourable context: regional/national & The transition initiative thinks it is well perceived by regional?national Transition Network hubs: Agree strongly; Agree, Neither agree nor disagree; \\
\hline & Transition Network hub & Disagree; Disagree strongly \\
\hline & $\begin{array}{l}\text { Favourable context: educational } \\
\text { institutions }\end{array}$ & $\begin{array}{l}\text { The transition initiative thinks it is well perceived by research/educational institutions: Agree strongly; Agree, Neither agree nor disagree; Disagree; } \\
\text { Disagree strongly }\end{array}$ \\
\hline
\end{tabular}


Table A.2. Geographical distribution of the population* and sample ${ }^{\star *}$ of transition initiatives.

\begin{tabular}{|c|c|c|c|c|}
\hline \multirow[b]{2}{*}{ Country } & \multicolumn{2}{|c|}{ Population } & \multicolumn{2}{|c|}{ Sample } \\
\hline & $\mathrm{N}$ & $\%$ & $\mathrm{~N}$ & $\%$ \\
\hline Argentina & 2 & 0.2 & 1 & 0.4 \\
\hline Australia & 82 & 7.0 & 18 & 6.5 \\
\hline Austria & 5 & 0.4 & 1 & 0.4 \\
\hline Bangladesh & 1 & 0.1 & 0 & 0.0 \\
\hline Belgium & 17 & 1.4 & 7 & 2.5 \\
\hline Brazil & 4 & 0.3 & 5 & 1.8 \\
\hline Canada & 67 & 5.7 & 17 & 6.2 \\
\hline Chile & 2 & 0.2 & 2 & 0.7 \\
\hline Denmark & 5 & 0.4 & 2 & 0.7 \\
\hline Finland & 1 & 0.1 & 0 & 0.0 \\
\hline France & 62 & 5.3 & 11 & 4.0 \\
\hline Germany & 71 & 6.0 & 15 & 5.4 \\
\hline Greece & 2 & 0.2 & 0 & 0.0 \\
\hline Hungary & 2 & 0.2 & 0 & 0.0 \\
\hline India & 1 & 0.1 & 0 & 0.0 \\
\hline Ireland & 27 & 2.3 & 3 & 1.1 \\
\hline Isle of Man & 1 & 0.1 & 0 & 0.0 \\
\hline Italy & 29 & 2.5 & 10 & 3.6 \\
\hline Japan & 3 & 0.3 & 0 & 0.0 \\
\hline Latvia & 1 & 0.1 & 1 & 0.4 \\
\hline Luxembourg & 1 & 0.1 & 0 & 0.0 \\
\hline Mauritius & 1 & 0.1 & 0 & 0.0 \\
\hline Mexico & 1 & 0.1 & 0 & 0.0 \\
\hline Mozambique & 1 & 0.1 & 1 & 0.4 \\
\hline Netherlands & 9 & 0.8 & 2 & 0.7 \\
\hline New Zealand & 59 & 5.0 & 4 & 1.4 \\
\hline Nigeria & 1 & 0.1 & 0 & 0.0 \\
\hline Norway & 3 & 0.3 & 2 & 0.7 \\
\hline Philippines & 1 & 0.1 & 0 & 0.0 \\
\hline Poland & 1 & 0.1 & 0 & 0.0 \\
\hline Portugal & 17 & 1.4 & 0 & 0.0 \\
\hline Saint Vincent and the Grenadines & 1 & 0.1 & 0 & 0.0 \\
\hline Slovenia & 1 & 0.1 & 0 & 0.0 \\
\hline South Africa & 2 & 0.2 & 1 & 0.4 \\
\hline Spain & 9 & 0.8 & 4 & 1.4 \\
\hline Sweden & 6 & 0.5 & 4 & 1.4 \\
\hline Switzerland & 7 & 0.6 & 3 & 1.1 \\
\hline Taiwan & 1 & 0.1 & 0 & 0.0 \\
\hline Thailand & 1 & 0.1 & 0 & 0.0 \\
\hline United Kingdom & 377 & 32.0 & 107 & 38.8 \\
\hline United States of America & 294 & 24.9 & 55 & 19.9 \\
\hline TOTAL & 1179 & 100 & 276 & 100.0 \\
\hline
\end{tabular}

* Sources: Transition Network website and national hubs (United States of America, Ireland, Norway, Sweden, The Netherlands, Canada, Japan, Australia, United Kingdom, New Zealand, France, Portugal, Brazil, Germany, Switzerland, Spain, Chile, and Italy). These figures are to be intended as estimates due to the volatile nature of Tls.

** Only valid responses shown. 
Table A.3. Official and mulling transition initiatives as listed in the Transition Network website and in the sample.

\begin{tabular}{l|cc|cc}
\hline & \multicolumn{2}{|c|}{ Population* } & \multicolumn{2}{c}{ Sample } \\
Variable & $\mathrm{N}$ & $\%$ & $\mathrm{~N}$ & $\%$ \\
\hline Official & 421 & 40.4 & 158 & 57.2 \\
Mulling & 620 & 59.6 & 128 & 46.4 \\
TOTAL & 1041 & 100.0 & 276 & 100.0 \\
\hline
\end{tabular}

* As indicated in the Transition Network website (accessed in June 2012). 
Table A.4. Characteristics of a successful transition initiative (aggregated data for first, second and third most important characteristics).

\begin{tabular}{|c|c|c|}
\hline Factor & Characteristic & $\begin{array}{l}\text { Total times } \\
\text { mentioned }\end{array}$ \\
\hline \multirow[t]{9}{*}{ Human factors } & $\begin{array}{l}\text { Critical mass of active volunteers/members, community } \\
\text { involvement }\end{array}$ & 88 \\
\hline & $\begin{array}{l}\text { Enthusiasm, positive approach, energy, commitment, } \\
\text { ambition }\end{array}$ & 69 \\
\hline & Inclusiveness, diversity & 39 \\
\hline & Patience, perseverance, continuity of activities, resilience & 34 \\
\hline & Conviviality, harmony, sense of community, collaboration & 32 \\
\hline & Fun, happiness, enjoyability, celebration & 26 \\
\hline & Integrity, honesty, respect, tolerance, ability to listen & 17 \\
\hline & Appropriation, empowerment, inner transition & 9 \\
\hline & Common values and beliefs, likemindness, cohesion & 4 \\
\hline \multirow[t]{4}{*}{ External factors } & Non-specified partnership/networking & 24 \\
\hline & Partnership/networking with other organizations & 18 \\
\hline & Partnership with local government & 11 \\
\hline & Place size/favourable local population/mass media & 4 \\
\hline \multirow[t]{13}{*}{ Organisation } & $\begin{array}{l}\text { Effectiveness, practical/concrete focus, achievement of } \\
\text { goals, active presence in society }\end{array}$ & 84 \\
\hline & Knowledge, awareness raising, education, information & 46 \\
\hline & Leadership, core group & 34 \\
\hline & Planning, vision, clear goal/purpose, inspiration & 30 \\
\hline & Visibility, events & 30 \\
\hline & Communication (internal/external) & 26 \\
\hline & Flexibility, open-ended, simplicity, "let it go" & 19 \\
\hline & Democratic, non-hierarchical, non-burocratical process & 16 \\
\hline & Creativity, ideas & 15 \\
\hline & Conflict resolution, organisation and groupwork skills & 14 \\
\hline & Opennes & 10 \\
\hline & Working groups & 7 \\
\hline & Self-awareness, learning from mistakes & 3 \\
\hline \multirow[t]{2}{*}{ Resources } & Financial resources & 15 \\
\hline & Time & 7 \\
\hline Other & & 36 \\
\hline
\end{tabular}


Table A5. Means of internal and external communication available to transition initatives.

\begin{tabular}{|c|c|c|c|c|c|c|c|}
\hline \multirow[b]{2}{*}{ Variables } & & \multicolumn{2}{|c|}{ Active transition initiatives } & \multicolumn{2}{|c|}{ Non-active transition initiatives } & \multicolumn{2}{|c|}{ All transition initiatives } \\
\hline & & $\mathbf{N}$ & $\%$ & $\mathbf{N}$ & $\%$ & $\mathbf{N}$ & $\%$ \\
\hline \multirow[t]{7}{*}{ Internal communication } & Personal contacts & 163 & 62.9 & 11 & 64.7 & 174 & 63.0 \\
\hline & Workshops & 56 & 21.6 & 2 & 11.8 & 58 & 21.0 \\
\hline & Communication events & 58 & 22.4 & 2 & 11.8 & 60 & 21.7 \\
\hline & Website & 122 & 47.1 & 2 & 11.8 & 124 & 44.9 \\
\hline & Electronic materials (e.g. newsletter) & 170 & 65.6 & 9 & 52.9 & 179 & 64.9 \\
\hline & Printed materials & 19 & 7.3 & 1 & 5.9 & 20 & 7.2 \\
\hline & Other & $77 \S$ & 29.7 & $4 *$ & 23.6 & 81 & 29.3 \\
\hline \multirow[t]{7}{*}{ External communication } & Personal contacts & 161 & 62.2 & 10 & 58.8 & 171 & 62.0 \\
\hline & Workshops & 103 & 39.8 & 6 & 35.3 & 109 & 39.5 \\
\hline & Communication events & 139 & 53.7 & 5 & 29.4 & 144 & 52.2 \\
\hline & Website & 185 & 71.4 & 5 & 29.4 & 190 & 68.8 \\
\hline & Electronic materials (e.g. newsletter) & 136 & 52.5 & 6 & 35.5 & 142 & 51.4 \\
\hline & Printed materials & 102 & 39.4 & 5 & 29.4 & 107 & 38.8 \\
\hline & Other (phone, social network) & $67 \S \S$ & 25.9 & $2^{* *}$ & 11.8 & 69 & 25.0 \\
\hline
\end{tabular}

* phone, emails; ** exibition, local press; § emails, online groups and social media; § emails, social media, local press. 
Table A6. 12 Steps to Transition (Brangwyn and Hopkins, 2008).

\begin{tabular}{cl}
\hline Number & Steps \\
\hline 1 & Set up a steering group and design its demise/transformation from the outset \\
2 & Start raising awareness \\
3 & Lay the foundations \\
4 & Organise a Great Unleashing \\
5 & Form theme (or special interest) groups \\
6 & Use Open Space \\
7 & Develop visible practical manifestations of the project \\
8 & Facilitate the Great Reskilling \\
9 & Build a bridge to Local Government \\
10 & Honour the elders \\
11 & Let it go where it wants to go... \\
12 & Create an Energy Descent Action Plan \\
\hline
\end{tabular}

